\title{
The behavior of nickel isotopes at the biogeochemical interface between ultramafic soils and $\mathrm{Ni}$ accumulator species
}

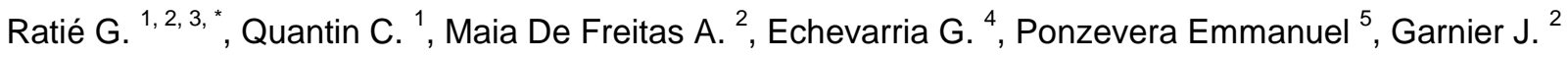 \\ ${ }^{1}$ UMR 8148 GEOPS, Université Paris Sud - CNRS - Université Paris Saclay, 91405 Cedex, France \\ ${ }^{2}$ UnB, IG/GMP-ICC Centro, Campus Universitário Darcy Ribeiro, 70910-970, Brasilia-DF, \\ Brazil/Laboratoire Mixte International "Observatoire des Changements Environnementaux" (LMI OCE), \\ Institut de Recherche pour le Développement/University of Brasilia, Campus Darcy Ribeiro, Brasilia, \\ Brazil \\ ${ }^{3}$ Synchrotron Soleil, L'Orme des Merisiers, Saint Aubin, BP 48, F-91192 Gif-sur-Yvette Cedex, France \\ ${ }^{4}$ Laboratoire Sols et Environnement, UMR 1120, Université de Lorraine-INRA, Vandoeuvre-lès-Nancy, \\ France \\ ${ }^{5}$ IFREMER, Centre de Brest, Unité Géosciences Marines, 29280 Plouzané, France \\ *Corresponding author : G. Ratié, email address : gildas.ratie@gmail.com
}

\begin{abstract}
Ultramafic derived soils are characterized by low nutrient soils, a low Ca:Mg ratio, and high metal contents such as $\mathrm{Ni}, \mathrm{Co}$ and $\mathrm{Cr}$. The vegetation growing on these soils is highly adapted and includes both $\mathrm{Ni}$ hyperaccumulator and accumulator species. Today, approximately $530 \mathrm{Ni}$ hyperaccumulator species are listed worldwide and the Ni concentration can be extremely high, e.g. up to $25 \%$ in latex from Pycnandra acuminata (Sapotaceae), a tree found in New Caledonia. The aim of this study is to identify the potential role of $\mathrm{Ni}$ hyperaccumulator plants in the $\mathrm{Ni}$ biogeochemical cycle at the soil surface by using $\mathrm{Ni}$ isotopes. A set of $\mathrm{Ni}$ hyperaccumulator and $\mathrm{Ni}$ accumulator plants as well as topsoils were sampled on the Barro Alto and Niquelândia ultramafic complexes (Goiás State, Brazil). Three $\mathrm{Ni}$ hyperaccumulator plants were collected: Justicia lanstyakii, Heliotropium aff. salicoides, Cnidoscolus aff. urens, as well as one $\mathrm{Ni}$ accumulator plant, Manihot $\mathrm{sp}$. The isotopic compositions of the whole plants were determined and compared to those of the bulk topsoils and DTPA-extractable Ni. The topsoils exhibited $\delta^{60} \mathrm{Ni}$ values ranging from $-0.30 \pm 0.06 \%$ o $0.16 \pm 0.05 \%$. The DTPA-extractable $\mathrm{Ni}$ in the topsoils ranged from 94 to $623 \mathrm{mg} \mathrm{kg}^{-1}$, i.e. $0.9-4.9 \%$ of the total soil $\mathrm{Ni}$ and was found to be isotopically heavier than the corresponding topsoil (from $-0.30 \pm 0.05 \%$ o to $0.34 \pm 0.08 \%$ ). The $\delta^{60} \mathrm{Ni}$ values for the $\mathrm{Ni}$ accumulator plants showed an enrichment in heavy $\mathrm{Ni}$ isotopes in the aerial parts of the plant compared to the roots, whereas similar $\delta^{60} \mathrm{Ni}$ values for the roots, stems and aerial parts suggested that no significant fractionation results from $\mathrm{Ni}$ uptake and translocation in $\mathrm{Ni}$ hyperaccumulator plants. Moreover, the aerial parts (i.e. leaves and flowers) from all of the plants analyzed showed the highest $\mathrm{Ni}$ concentrations and the heaviest $\delta^{60} \mathrm{Ni}$ values up to $1.21 \pm 0.05 \%$. The enrichment in heavy $\mathrm{Ni}$ isotopes in the leaves $\left(0.09 \pm 0.06 \%<\Delta^{60} \mathrm{Ni}_{\text {leaves-soil }}<1.06 \pm 0.03 \%\right.$ o $)$ may result in a heavy $\mathrm{Ni}$ input in the litter during organic matter restitution. There is a non-negligible amount of $\mathrm{Ni}$ uptake by $\mathrm{Ni}$ accumulator and $\mathrm{Ni}$ hyperaccumulator plants and this may modify both the $\mathrm{Ni}$ isotope composition at the soil-plant interface and the overall cycle of $\mathrm{Ni}$ in surface soils
\end{abstract}




\section{Highlights}

- DTPA extractable Ni in topsoil is isotopically heavier than the total Ni pool. $>$ Ni-accumulators exhibit enrichment in Ni heavy isotopes in aerial parts. Similar $\delta^{60} \mathrm{Ni}$ values for each plant compartment are observed for Ni-hyperaccumulators. Enrichment in heavy $\mathrm{Ni}$ isotopes in leaves may lead to a heavy $\mathrm{Ni}$ input in the litter.

Keywords : Nickel, Isotope, Ni hyperaccumulator species, Ultramafic environment 


\section{Introduction}

Ultramafic (UM) soils are characterized by strong chemical peculiarities: low nutrient contents $(\mathrm{N}, \mathrm{P}$, $\mathrm{K}$ ), a high $\mathrm{Mg}$ to $\mathrm{Ca}$ imbalance, and elevated contents of metals such as $\mathrm{Fe}, \mathrm{Mn}, \mathrm{Ni}$, $\mathrm{Co}$ and $\mathrm{Cr}$ (e.g. Walker, 1954; Whittaker, 1954; Proctor and Woodell, 1975; Becquer et al., 2010; Echevarria, 2018). Therefore, the natural vegetation growing on UM soils is adapted to the "serpentinic syndrome" (Whittaker, 1954; Proctor and Woodell, 1975). Plants growing on UM soils can be either adapted to nutrient deficiencies and/or high metal contents or be (hyper)accumulators of metals. In their dry weight, Ni hyperaccumulator plants contain foliar tissue $>1000 \mu \mathrm{g} \mathrm{g}^{-1}$ of $\mathrm{Ni}$ when growing in their natural habitat (Baker and Brooks, 1989; van der Ent et al., 2013; Reeves et al., 2017). This Ni concentration is 100 to 1000 times larger than the Ni concentration of plants grown on soil developed on non-UM rocks (Welch, 1981; Reeves et al., 2003; van der Ent et al., 2013).

Studies carried out over the past 40 years have focused on Ni (hyper)accumulators (e.g. Jaffré et al., 1976; Lee et al., 1977; Brooks et al., 1979; Reeves et al., 1983) to better understand the Ni accumulation phenomenon resulting from the stimulated uptake of $\mathrm{Ni}$ by the roots and an efficient transfer of Ni to the leaves through efficient xylem transport and phloem distribution (Centofanti et al., 2013; Tang et al., 2016; Deng et al., 2018), and to evaluate their phytomining and phytoremediation potential (e.g. Minguzzi and Vergnano, 1948; Reeves et al., 1996, 1999; Puschenreiter et al., 2005; Centofanti et al., 2012; van der Ent et al., 2015). In July 2017, the database listed $532 \mathrm{Ni}$ hyperaccumulator species (52 families and 130 genera) (Reeves et al. 2018). To date, these species are found worldwide and most of them grow on tropical and subtropical ultramafic soils (van der Ent et al., 2013). For example, foliar Ni concentrations up to $7.6 \mathrm{wt} \%$ are found in the Ni hyperaccumulator species Berkheya coddii from South Africa (Mesjasz-Przybylowicz et al., 2004), whereas 25\% Ni is found in latex from Pycnandra acuminata, a tree found in New Caledonia (Jaffré et al., 1976).

Therefore, the phenomenon of high Ni accumulation by plants on UM sites as reported by Reeves et al. (2018) raises the question of how the Ni biogeochemical cycle is modified or regulated by this biological process. The biogeochemical cycling of metals in both natural and contaminated systems 
can be accessed via isotope fractionation studies. These studies may be able to clarify the contribution of the different processes such as sorption, dissolution, lattice incorporation, complexation or biological uptake (Weiss et al., 2008; Bullen, 2014; Wiederhold, 2015). In order to understand the fractionation mechanisms occurring in $\mathrm{Ni}$ cycling at the soil-plant interface, $\mathrm{Ni}$ isotope systematics have been introduced in studies focusing on both $\mathrm{Ni}$ (hyper)accumulator plants in hydroponic conditions and on plants collected in the field (Deng et al., 2014; Estrade et al., 2015; Tang et al., 2016). Deng et al. (2014) described the $\mathrm{Ni}$ and $\mathrm{Zn}$ isotopic fractionation during hydroponic plant growth. Ni hyperaccumulator plant growth (Alyssum murale and Noccaea caerulescens) is characterized by an enrichment in light $\mathrm{Ni}$ isotopes in the aerial parts of the plant, whereas heavy isotope enrichment is observed from the roots to the aerial parts for $\mathrm{Ni}$ non-accumulator plants (Thlaspi arvense). A field study on UM soils from Albania carried out by Estrade et al. (2015) reported the composition of the $\mathrm{Ni}$ isotopes for the subterranean and aerial organs of $\mathrm{Ni}$ hyperaccumulator plants (Alyssum markgrafii, Alyssum murale and Alyssum bertolonii subsp. scutarinum) and a non-hyperaccumulator plant (Euphorbia spinosa) collected in a Mediterranean climate. These authors suggest that the very efficient $\mathrm{Ni}$ uptake by $\mathrm{Ni}$ hyperaccumulators inhibited $\mathrm{Ni}$ isotope fractionation and uptake via the roots in soil solution enriched in heavy $\mathrm{Ni}$ isotopes and seems to control the $\mathrm{Ni}$ isotopic composition in the Ni hyperaccumulator plant. Conversely, an enrichment in light $\mathrm{Ni}$ isotopes was observed during $\mathrm{Ni}$ translocation from the roots to the leaves for the Ni nonaccumulator plant (Euphorbia spinosa). Recently, Zelano et al. (2018) investigated the replenishment of the available Ni pools in soils by simulating litter decomposition using leaves from Alyssum murale and Rinorea bengalensis (hyperaccumulator plants). During the first days of leaching, the leaves released more than $80 \%$ of the total $\mathrm{Ni}$ content and the leached solution clearly displayed an enrichment in heavy isotopes for Rinorea bengalensis, while no isotope fractionation is observed for Alyssum murale. Therefore, the remaining litter could contain lighter Ni contents compared to the fresh leaves as also observed by Estrade et al. (2015). Consequently, these studies suggest that, in the upper soil horizons, the Ni cycle may be strongly affected by biological activity, particularly through the uptake of $\mathrm{Ni}$ in the roots of $\mathrm{Ni}$ hyperaccumulators, litterfall and litter recycling/biodegradation (Echevarria 2018). 
The goal of this article is to determine the $\mathrm{Ni}$ isotope composition of $\mathrm{Ni}$ hyperaccumulator and $\mathrm{Ni}$ accumulator plants in two UM massifs located in Brazil in order to document the $\mathrm{Ni}$ isotope fractionation occurring in situ in plant-soil systems and to evaluate the impact of $\mathrm{Ni}$ uptake by $\mathrm{Ni}$ (hyper)accumulator plants on the Ni biogeochemical surface cycle. Within this framework, the Ni isotopic composition of the roots and aerial organs from several specimens of three $\mathrm{Ni}$ hyperaccumulator plants and one Ni accumulator plant collected in the UM massifs of Barro Alto and Niquelândia (Goiás state, Brazil) is completed with 19 topsoils taken from the same locations (Ratié et al., 2016).

\section{Materials and Methods}

\subsection{Sampling and digestion}

A set of Ni hyperaccumulator and $\mathrm{Ni}$ accumulator plants was sampled on the UM complex of Barro Alto and Niquelândia in 2013 and 2014 at different vegetative stages. The plant selection was based on the works of Reeves et al. (2007) and Raous et al. (2008), who identified close to 30 species of Ni (hyper)accumulator plants in Niquelândia and Barro Alto (Goiás State, Brazil). Three Ni hyperaccumulator species were sampled according to their abundance in the massif and they were identified by their flowering: Justicia lanstyakii (four specimens), Heliotropium aff. Salicoide (six specimens), Cnidoscolus aff. urens (three specimens), as well as one $\mathrm{Ni}$ accumulator species: Manihot $s p$. (four specimens) (Fig. 1). At each plant location, the bulk topsoil $(0-5 \mathrm{~cm})$ was also sampled, dried and sieved at $2 \mathrm{~mm}$ (Ratié et al., 2016).

The plant samples were carefully dry washed and rinsed with MilliQ® water in order to avoid soil contamination. They were then dried, finely cut and homogenized. Acid digestion was performed in a clean lab at the University of Brasilia with a microwave (Speedwave 4, Berghof). All of the reagents used in the digestion procedure were of analytical grade and bi-distilled. Approximately $300 \mathrm{mg}$ of the samples was digested in Teflon bombs with $9 \mathrm{~mL}$ of concentrated $\mathrm{HNO}_{3}, 3 \mathrm{~mL}$ of $\mathrm{HF}, 2 \mathrm{~mL}$ of $\mathrm{HCl}$ and $1 \mathrm{~mL}$ of $\mathrm{H}_{2} \mathrm{O}_{2}$ under three successive conditions $\left(150^{\circ} \mathrm{C}, 30\right.$ bars; $190^{\circ} \mathrm{C}, 35$ bars; $50^{\circ} \mathrm{C}, 25$ bars $)$. The leachates were subsequently evaporated to dryness then taken up with $6 \mathrm{M} \mathrm{HCl}$ for the 
chromatographic separation of Ni. The same acid digestion was also performed on two international standards. The measured Ni concentrations were $2.5 \pm 0.2 \mathrm{mg} \mathrm{kg}^{-1}$ and $0.9 \pm 0.1 \mathrm{mg} \mathrm{kg}^{-1}$ in NIST SRM 1570a Spinach Leaves and NIST SRM 1515 Apple Leaves, respectively, in agreement with the NIST publication.

The soil samples were homogenized and finely ground before acid digestion. Approximately $100 \mathrm{mg}$ of the samples was digested in Teflon vessels with $5 \mathrm{~mL}$ of concentrated $\mathrm{HF}$ and $1.5 \mathrm{~mL}$ of $\mathrm{HClO}_{4}$ at $180^{\circ} \mathrm{C}$ and then evaporated to dryness. They were subsequently digested in a mixture of concentrated $\mathrm{HNO}_{3}-\mathrm{HCl}\left(3.75 \mathrm{~mL}\right.$ of $\mathrm{HCl}$ and $1.25 \mathrm{~mL}$ of $\left.\mathrm{HNO}_{3}\right)$ at $150^{\circ} \mathrm{C}$ and evaporated to dryness. The samples were then taken up with $6 \mathrm{M} \mathrm{HCl}$ for chromatography separation of Ni (Ratié et al., 2015) and an aliquot were evaporated to dryness and taken up with $0.5 \mathrm{M} \mathrm{HNO}_{3}$ to perform the chemical measurements.

\subsection{Geochemical analysis}

Measurements of the $\mathrm{Ca}, \mathrm{Fe}, \mathrm{Mg}, \mathrm{Ni}, \mathrm{Ca}, \mathrm{K}, \mathrm{Mn}$ and $\mathrm{Na}$ concentrations were performed by AAS (Varian, AA240FS, Fast Sequential Atomic Absorption Spectrometer, GEOPS-Université Paris Sud) The accuracy of the AAS measurements was controlled using standard solutions (EPL3, EPH3 and ESH2, SCP Science) and were always higher than $8 \%$ relative standard deviation (RSD) with respect to the certified values for the reference materials. $\mathrm{N}_{\text {tot }}$ and organic content (OC) measurements and the determination of $\delta^{13} \mathrm{C}$ and $\delta^{15} \mathrm{~N}$ were performed at GEOPS by EA-IRMS (VG SIRA 10).

Nickel availability was determined by extraction with $0.005 \mathrm{M} \mathrm{DTPA}+0.01 \mathrm{M} \mathrm{CaCl}_{2}$ buffered at $\mathrm{pH}$ 5.3 (L'Huillier and Edighoffer, 1996). Suspensions with 1:5 soil:solution ratio (w/v) were mixed endover-end for $2 \mathrm{~h}$, and subsequently centrifuged, filtered at $0.45 \mu \mathrm{m}$ (Millipore ${ }^{\circledR}$ ), and the extracts were analyzed with AAS to determine the Ni content. The extracts were evaporated and digested with concentrated acids using the same protocol used for the soil samples and analyzed for isotopic measurements after appropriate Ni purification. 


\subsection{Nickel isotopes}

The Ni chemical purification procedure for the samples is based on a two-step chromatography separation that is fully described in Ratié et al. (2015). A first set of ion-exchange chromatography columns is filled with $2 \mathrm{~mL}$ (wet volume) of anionic resin AG1-X8 in $6 \mathrm{M} \mathrm{HCl}$ (BioRad 100-200 mesh). This resin retains $\mathrm{Fe}, \mathrm{Zn}$ and a high amount of $\mathrm{Co}$ and $\mathrm{Cu}$ (Moynier et al., 2007) while Ni remains in the solution. Before the second chromatography column, a Ni double spike $\left({ }^{61} \mathrm{Ni}\right.$ and $\left.{ }^{62} \mathrm{Ni}\right)$ is added to the samples with a spike/natural ratio of 1 (Gueguen et al., 2013). The second set of ionexchange chromatography columns use a specific Ni-resin (Eichrom) composed of polymethacrylate containing a dimethylglyoxime (DMG) molecule that retains $\mathrm{Ni}$ onto the resin as an insoluble NiDMG complex at $\mathrm{pH} 8-9$. The eluted $\mathrm{Ni}$ solution is evaporated and taken up in $\mathrm{HNO}_{3} 2 \%$.

The Ni isotope ratios were measured with a Neptune (Thermo-Electron) MC-ICP-MS at the Pôle Spectrométrie Océan (PSO) at IFREMER (Centre de Brest, France). The samples and standards were introduced via an ApexQ (50-75 V per $\mu \mathrm{g} / \mathrm{mL})$ in $\mathrm{HNO}_{3} 2 \%$. A single "run" consisted of one block of 40 measurements. During the measurement, the Ni concentration (spike + natural) in the sample is 200 $\mu \mathrm{g} / \mathrm{L}\left({ }^{61} \mathrm{Ni} /{ }^{62} \mathrm{Ni}=1.1004\right.$ with a total Ni concentration of $100 \mathrm{mg} / \mathrm{L}$; Gueguen et al. (2013). The double-spike calculation procedure was based upon the method described by Siebert et al. (2001) for the determination of Mo isotopes. This method consists of determining the corrected isotopic ratio and instrumental mass bias through iterative calculations (Albarede and Beard, 2004; Quitté and Oberli, 2006; Cameron et al., 2009). In addition, each sample analysis was bracketed by the measurements of the spiked standard Ni NIST SRM 986 solutions at the same concentration and same spike/standard ratio as the samples. The $\delta^{60} \mathrm{Ni}$ ratios were expressed in per mil (\%) and normalized to the average value of the bracketing standard SRM-986 (Eq. 1) (Gramlich et al., 1989).

$$
\delta^{60} N i=\left(\frac{\left(\frac{\delta^{60} N i}{\delta^{58} N i}\right)_{S p l e}}{\left(\frac{\delta^{60} N i}{\delta^{58} N i}\right)_{S R M-986}}-1\right) \times 1000(\text { Eq. 1) }
$$

The long-term analytical sample reproducibility of the Ni standard NIST SRM 986 was $\pm 0.05 \%$ o (2 $\mathrm{SD}, \mathrm{n}=320$ ). The average $\delta^{60} \mathrm{Ni}$ reproducibility of the sample after the full chemical procedure 
(purification and measurement) was determined by measuring two samples four times each. This reproducibility was better than $0.03 \%$. Although each sample was measured three to four times, we only report the average values and their 2 SD values calculated from the replicate measurements (in the figures and tables). Note that a 2 SD value of $0.05 \%$ (external reproducibility) was reported when the calculated 2 SD was less than $0.05 \%$. A procedural blank sample was included within each batch of samples. The average amount of $\mathrm{Ni}$ for the blanks was $17 \mathrm{ng}(\mathrm{n}=8)$, which is negligible relative to the amount of $\mathrm{Ni}$ that was processed for each sample (usually 8-10 $\mu \mathrm{g}$ of $\mathrm{Ni}$ ).

\section{Results \& Discussion}

\subsection{Soil chemistry}

\subsubsection{Bulk composition}

The main characteristics of the UM soils of Barro Alto and Niquelândia are detailed in Ratié et al. (2015) and (2016) and the chemical and Ni isotope compositions are summarized in Table 1. The soil samples are rich in metals such as Fe $\left(378 \pm 77 \mathrm{~g} \mathrm{~kg}^{-1}\right), \mathrm{Ni}\left(10.2 \pm 3.3 \mathrm{~g} \mathrm{~kg}^{-1}\right)$ and $\mathrm{Mg}\left(16.4 \pm 8.1 \mathrm{~g} \mathrm{~kg}^{-}\right.$ $\left.{ }^{1}\right)$ compared to $\mathrm{Ca}\left(2.9 \pm 2.9 \mathrm{~g} \mathrm{~kg}^{-1}\right)$, and very poor in $\mathrm{K}\left(0.1 \pm 0.1 \mathrm{~g} \mathrm{~kg}^{-1}\right)$. The soil chemistry is in accordance with other soils analyzed in tropical UM environments, such as in Brazil, Cuba and New Caledonia (Reeves et al., 1999, 2007, Becquer et al., 2001; Massoura et al., 2006; Garnier et al., 2009). In comparison with other studies on $\mathrm{Ni}$ isotopes in soils and plants, the $\mathrm{Ni}$ contents in soils are significantly higher than those of the UM soils studied by Estrade et al. (2015) (1.4-3.8 $\mathrm{g} \mathrm{kg}^{-1}$ ) and Pędziwiatr et al. (2018) $\left(0.82-2.1 \mathrm{~g} \mathrm{~kg}^{-1}\right)$. The soil mineralogy is dominated by iron oxide (goethite, hematite), spinel (i.e., chromite and/or magnetite) and quartz (Garnier et al., 2006, 2009; Ratié et al., 2015). In non-serpentinized UM soils developed in humid tropical conditions, the main Ni-bearing phases are goethite and Mn-oxides (Echevarria et al., 2006). Nickel is mainly hosted by goethite in the soils of Barro Alto and Niquelândia. Moreover, the soils present high $\mathrm{OC}$ and $\mathrm{N}_{\text {tot }}$ contents ranging from 1.61 to $5.40 \%$ and from 0.08 to $0.33 \%$, respectively. Nickel may also be hosted by organic matter $(\mathrm{OM})$ as demonstrated by its affinity to bind to OM (e.g. Saar and Weber, 1982; Buffle, 1988; McCarthy and Zachara, 1989). 
The soil samples were acidic ( $\mathrm{pHw}=5.2-6.8)$, and the $\Delta \mathrm{pH}\left(\mathrm{pH}_{\mathrm{KCl}}-\mathrm{pHw}\right)$, ranging from -1.84 to -0.42 , indicating that the acidity reserve was very high and that negative charges prevailed in these soil samples, in relation to the significant organic content (up to $5.4 \mathrm{wt} \%$ ). The isotope composition for $\delta^{13} \mathrm{C}$ and $\delta^{15} \mathrm{~N}$ ranges from -25.65 to $-15.63 \%$ and from 4.30 to $7.60 \%$, respectively. The $\delta^{13} \mathrm{C}$ values of soils from Niquelândia are clearly lighter than for soils from Barro Alto and therefore it appears that the origin of the OC is different between the two ultramafic sites.

\subsubsection{Nickel availability in the soil samples}

The DTPA-extractable Ni ranged from 14 to $623 \mathrm{mg} \mathrm{kg}^{-1}(\mathrm{n}=18)$, representing 0.3 to $4.9 \%$ of the total Ni. These DTPA-extractable Ni concentrations were in the same range as those reported for UM soils developed in a tropical environment on Mt Kinabalu, Malaysia (van der Ent et al., 2018) and in New Caledonia (Perrier et al., 2006). However, in temperate climates, values ranging from 1.48 to $10.5 \%$ in the A horizons of Albanian and Czech UM soils and 3.4 to $8.4 \%$ in rhizospheric soils were reported (Quantin et al., 2008, Bani et al., 2014; Estrade et al. 2015). More recently, Pędziwiatr et al. (2018) reported a comparable proportion of DTPA-extractable Ni in A horizons of UM soils (4.0$6.8 \%$ ) in Lower Silesia (Poland).

The DTPA-extractable Ni pool of topsoils corresponds to the Ni pool from which hyperaccumulators and non-accumulators take up Ni (Massoura et al., 2005; Chardot et al., 2005); this makes it a suitable method to assess the chemical pool accessible to plants. Ni availability may be more strongly influenced by the biogeochemical recycling of litter, and therefore, soil organic matter may host a significant fraction of available $\mathrm{Ni}$ after the decay of Ni-rich litter, demonstrating the strong correlation between Ni-DTPA with total organic carbon (Bani et al., 2014). However, even if DTPA extraction has been shown to be able to efficiently determine the amount of Ni available for plants (Echevarria et al., 1998, 2006), in some cases it could underestimate the actual phytoavailability of Ni because the extraction period was too short or because of Ni oversaturation (Kukier and Chaney, 2001; Echevarria et al., 2006). This may have an influence on the isotopic composition of the phytoavailable Ni determined by DTPA extraction (Estrade et al., 2015). 
The DTPA-extractable Ni was within the same range as the values reported for UM soils developed in a tropical environment (Perrier et al., 2006; van der Ent et al., 2018), ranging from 14 to $623 \mathrm{mg} \mathrm{kg}^{-1}$ $(n=18)$, representing 0.3 to $4.9 \%$ of the total $\mathrm{Ni}$.

\subsubsection{Ni isotope compositions of the soil samples}

The $\delta^{60} \mathrm{Ni}$ values for the soil samples collected in Barro Alto and Niquelândia range from $-0.30 \pm$ $0.06 \%$ to $0.16 \pm 0.05 \%$ (Tab. 1 , Ratié et al., 2015, 2016). This Ni isotope composition is consistent with the values found for the UM soils studied by Estrade et al. (2015) in Albania, but lighter than those reported by Pędziwiatr et al. (2018). In Barro Alto, Ratié et al. (2015) have also reported $\delta^{60} \mathrm{Ni}$ values from three horizons of one soil profile in the same area ranging from -0.19 to $-0.02 \%$. The range of $\delta^{60} \mathrm{Ni}$ values of soils appear to be primarily isotopically light compared to UM rocks and slightly weathered materials from Barro Alto and Niquelândia (from 0.10 to $0.32 \pm 0.05 \%$; Ratié et al., 2015, 2018) as well as Bulk Silicate Earth, the isotopic composition of which was first estimated as $0.05 \pm 0.05 \%$ (Gueguen et al., 2013) and recently reevaluated to be $0.23 \pm 0.08 \%$ (Gall et al., 2017). Although $\mathrm{Ni}$ appears to be associated to goethite in the mineral horizons or to $\mathrm{OM}$ in the topsoils, Figure 2 shows that no correlation is observed between the $\delta^{60} \mathrm{Ni}$ values and the Fe/Ni ratio (Fig. 2a), while the heaviest $\mathrm{Ni}$ isotope signature corresponds to the largest OC/Ni ratio (Fig. 2b) suggesting that $\delta^{60} \mathrm{Ni}$ could be controlled by OM mainly coming from litter decomposition.

The $\delta^{60} \mathrm{Ni}$ values for the extracted Ni-DTPA present a wide variability from $-0.30 \pm 0.05 \%$ to $0.34 \pm$ $0.05 \%$ (Tab. 1). A trend towards heavy Ni isotope enrichment in the DTPA solution relative to the soil is observed (Fig. 2c). These results are in line with the work of Estrade et al. (2015), who showed that the Ni isotope composition of the Ni-DTPA fraction was systematically heavier than that of the soil and thus strongly influenced by the water-soluble fraction of Ni. As discussed previously, the possible incomplete extraction of bioavailable $\mathrm{Ni}$ in the DTPA solution may induce a bias in the Ni isotopic measurement of this pool, as $\delta^{60} \mathrm{Ni}_{\text {DTPA }}$ depends on the yield of the extraction and the isotopic fractionation range during the chemical reaction (Estrade et al., 2015). Moreover, the significant variability in the $\delta^{60} \mathrm{Ni}$ values makes it complicated to assert that the isotopic composition of the DTPA extraction represents the isotopic signature of the Ni pool bioavailability for plants. However, it 
is not excluded that this variability is natural and related to the properties of the soil as discussed above. Moreover, when tracing the available Ni with radioactive ${ }^{63} \mathrm{Ni}$, Echevarria et al. (1998) were able to demonstrate that the DTPA-extractable pool of $\mathrm{Ni}$ in one soil had the same isotopic composition as $\mathrm{Ni}$ in the soil solution, thus showing that DTPA-extractable Ni can be in chemical equilibrium with the $\mathrm{Ni}$ in the soil solution after a long period of tracing. This heavy $\mathrm{Ni}$ isotope enrichment in the available Ni pool shows that the Ni that is accessible to plants comes from another source than the $\mathrm{Ni}$ pool associated with iron oxides (i.e. characterized by a light $\mathrm{Ni}$ isotope composition) and thus potentially from the Ni released during litter decay. Therefore, Ni-bearing phases play an important role in determining the isotopic composition of the available Ni. Given that goethite (i.e. the dominant Ni-bearing phase in tropical UM soils) acts as a stable sink for metal in Nirich soils (Echevarria et al., 2006), the availability of the Ni contained in the sink was extremely low and thus another Ni-bearing phase (i.e. organic matter) must be responsible for this heavy isotope enrichment of the DTPA-extractable pool.

\subsection{Plant chemistry}

The chemical composition of the plant organs (root, steam, leaf and flower) is described in the supplementary information (Tab. 2). For each specimen, the translocation factors (TF) showed that the aerial parts were enriched in $\mathrm{Mg}, \mathrm{Fe}$ and $\mathrm{Ni}$ compared to the roots and bulk soil, and that they were also enriched in $\mathrm{Ca}$ and $\mathrm{K}$ despite their low concentrations in these $\mathrm{UM}$ environments. Figure 3 shows the evolution of the $\mathrm{Ni}$ concentration from the soil to the aerial part with a Ni content exceeding 1000 $\mathrm{mg} \mathrm{kg}^{-1}$ in the leaves of the Justicia lanstyakii $\left(1591 \pm 817 \mathrm{mg} \mathrm{kg}^{-1}\right)$ and Heliotropium aff. Salicoides specimens $\left(1446 \pm 716 \mathrm{mg} \mathrm{kg}^{-1}\right)$ and in Cnidoscolus aff. Urens flowers $\left(978 \pm 754 \mathrm{mg} \mathrm{kg}^{-1}\right)$. In contrast with Estrade et al. (2015), the Ni concentrations in hyperaccumulator plants were somewhat different from the Ni content in the Ni-DTPA fraction. This lower accumulation could be explained by lower amount of DTPA-extractable Ni or by Ni uptake at a greater depth by the roots.

The leaves from Ni accumulator plants (i.e. Manihot sp. specimens) contained Ni concentrations of $331 \pm 241 \mathrm{mg} \mathrm{kg}^{-1}$, i.e. four to five times less $\mathrm{Ni}$ than the leaves of $\mathrm{Ni}$ hyperaccumulator plants. In the 
literature, plants growing on uncontaminated and non-UM soils have Ni contents ranging from 0.05 to $5 \mathrm{mg} \mathrm{kg}^{-1}$ (Welch, 1981). Ni (hyper)accumulator plants possess up to 300 times the maximum concentration of non-accumulator plants.

Figure 3 also shows highly diverse chemical compositions for the various specimens of the same species collected in the same area and between the two UM sites (Barro Alto and Niquelândia). Reeves et al. (2007) also showed this high variability in the Ni contents in plants growing on the ultramafic soils of Goiás, where the Ni contents varied from 274 to $2690 \mathrm{mg} \mathrm{kg}^{-1}$ for Justicia Lanstyakii, from 96 to $2015 \mathrm{mg} \mathrm{kg}^{-1}$ for Heliotropium aff. Salicoides and from 156 to $1019 \mathrm{mg} \mathrm{kg}^{-1}$ for Cnidoscolus aff. urens. Up until now, it is unclear why this variability exists; however, it could be related to the different soil conditions and, in particular, to $\mathrm{Ni}$ solid speciation and its subsequent bioavailability, as well as the age, growth stage and genetic internal physiological differences among the specimens and species (Reeves et al., 2007). As previously described, the $\delta^{13} \mathrm{C}$ value for soils from Niquelândia and Barro Alto clearly have two distinct origins for the $\mathrm{OC}$ which could be explained by the different chemical composition of the various specimens. Centofanti et al. (2012) demonstrated under controlled conditions that the $\mathrm{Ni}$ uptake by Alyssum corsicum (Ni hyperaccumulator species) is related to the solubility of the mineral species present in the soil. These factors must be taken into account when explaining this spatial variability in the elemental content in plants, as well as the intraspecimen genetic differences and growth stages.

\subsection{Overall $\mathrm{Ni}$ isotopic trend during $\mathrm{Ni}$ uptake by plants}

The Ni isotopic compositions of the various plant parts are presented in Figure 3 and all of the $\delta^{60} \mathrm{Ni}$ values are given in Table 2 . The $\Delta^{60} \mathrm{Ni}(\%)$ values calculated with the $\delta^{60} \mathrm{Ni}$ mean value for each part of the plant are provided in Table 3. There is a high intra-specimen variability giving large error ranges (Fig. 3).

The $\delta^{60} \mathrm{Ni}$ values in Justicia lanstyakii roots vary from $-0.47 \pm 0.08 \%$ to $0.03 \pm 0.11 \%$ o $(\mathrm{n}=4)$ and are close to those of the Ni-DTPA extracts. Justicia lanstyakii leaves are enriched in heavy Ni isotopes relative to the stems $\left(\Delta^{60} \mathrm{Ni}_{\text {leaves-stems }}=0.24 \pm 0.17 \%\right.$ o). In contrast with Justicia lanstyakii, the $\delta^{60} \mathrm{Ni}$ 
values in Heliotropium aff. Salicoide and Cnidoscolus aff. urens roots range from $-0.12 \pm 0.05$ to 0.43 $\pm 0.06 \%$ and from $0.52 \pm 0.05 \%$ o to $0.55 \pm 0.07 \%$, respectively, showing a heavier Ni isotope composition than that for the corresponding Ni-DTPA extracts $(-0.21 \pm 0.05 \%$ o to $0.07 \pm 0.06 \%$ ). Similarly to Justicia lanstyakii, Heliotropium aff. salicoides and Cnidoscolus aff. urens leaves are enriched in heavy $\mathrm{Ni}$ isotopes compared to the stems $\left(\Delta^{60} \mathrm{Ni}_{\text {leaves-stems }}=0.11 \pm 0.12 \%\right.$ and $\Delta^{60} \mathrm{Ni}_{\text {leaves- }}$ stems $=0.85 \pm 0.15 \%$, respectively). The $\delta^{60} \mathrm{Ni}$ values for Manihot $s p$. follow the trends observed for the three Ni hyperaccumulator plants. The stems present a range of $\delta^{60} \mathrm{Ni}$ values from $0.01 \pm 0.10 \%$ to $0.45 \pm 0.08 \%$ o $(n=4)$, while the leaves exhibit heavier $\delta^{60} \mathrm{Ni}$ values from $0.37 \pm 0.11 \%$ to $0.92 \pm$ $0.06 \%$ o $(n=4)$.

No linear trend from the roots to the leaves is observed for the Ni hyperaccumulator plants. However, two trends are observed (Tab. 3): (1) the stems are more enriched in light $\mathrm{Ni}$ isotopes than the roots ($0.22 \pm 0.19 \% \%_{0}<{ }^{60} \mathrm{Ni}_{\text {-stems-roots }}<-0.02 \pm 0.19 \%$ ) and (2) the leaves are more enriched in heavy $\mathrm{Ni}$ isotopes than the stems $\left(0.11 \pm 0.12 \%<\Delta^{60} \mathrm{Ni}_{\text {leaves-stems }}<0.85 \pm 0.15 \%\right.$ o $)$. In the case of the $\mathrm{Ni}$ accumulator plant, all of the Manihot sp. specimens showed a trend of heavy $\mathrm{Ni}$ isotope enrichment during the translocation process from the roots to the leaves $\left(\Delta^{60} \mathrm{Ni}_{\text {leaves-roots }}=0.41 \pm 0.17 \%\right.$ o $)(\mathrm{Tab} .3)$.

Estrade et al. (2015) showed that Ni hyperaccumulator plants collected within a UM context (Alyssum murale and bertolonii) in a Mediterranean climate (Albania) did not present any significant changes in terms of the isotopic composition among the various organs of the plant. These authors argued that the large amount of $\mathrm{Ni}$ transferred to the plant, which was redistributed through phloem flow in the flowering stage, could suppress $\mathrm{Ni}$ isotope fractionation (Estrade et al., 2015). Conversely, the results obtained for Ni hyperaccumulator plants in a hydroponic solution (i.e. under controlled conditions) showed an enrichment in light isotopes in the aerial parts (Deng et al., 2014). Accordingly, in the present study, all of the stems from $\mathrm{Ni}$ hyperaccumulator plants are enriched in light $\mathrm{Ni}$ isotopes compared with the roots $\left(-0.22 \pm 0.19 \%{ }_{0}<\Delta^{60} \mathrm{Ni}_{\text {stems-roots }}<-0.02 \pm 0.19 \%\right.$ )

Later, it was confirmed for Ni hyperaccumulator plants that an enrichment of Ni was found in the leaf phloem exudates (Tang et al., 2016). Nickel is primarily complexed by citrate in P. balgooyi (van der 
Ent et al., 2017), while malate is the main chelator for phloem $\mathrm{Ni}$ in $N$. caerulescens (Tang et al., 2016). Unlike xylem flow (Centofanti et al., 2013), Nickel translocation in phloem is therefore regulated by carboxylic acid complexation. For Alyssum species, phloem redistribution is at its maximum in the flowering stage, which explains why the fractionation between the roots, stems, leaves and flowers was null at this stage (Estrade et al., 2015). Therefore, the redistribution of Ni via the phloem could be responsible for the $\mathrm{Ni}$ isotope composition observed for the Ni hyperaccumulator species studied in this present work.

\subsection{Implications for the Ni cycle in surface soils}

Several studies have shown that the metal solubilization and accumulation mechanism mediated by plants does not cause soil acidification (Bernal et al., 1994; McGrath et al., 1997; Zhao et al., 2001). However, it is evident that plants secrete organic acids or amino acids intended for the chelation of metallic elements (Briat and Lebrun, 1999; Puschenreiter et al., 2003; Wenzel et al., 2003). Some hyperaccumulators may also enhance mineral dissolution to improve their Ni uptake (Chardot-Jacques et al., 2013). This contribution modified the soil edaphic conditions and may increase the bioavailable Ni content and consequently may potentially modify its Ni isotopic signature. Moreover, Zelano et al. (2018) observed that, under their experimental conditions, Ni binding by carboxylic acids such as citric and oxalic acids produced a very small $\mathrm{Ni}$ fractionation compared to free $\mathrm{Ni}$ in the solution $\left(\Delta^{60} \mathrm{Ni}_{\text {bound-free }}<0.2 \%\right.$ ), while complexation with purified humic acid did not show any fractionation.

The leaves, which are the main constituents of the Brazilian "Cerrado" litter, are the plant compartments with the highest $\mathrm{Ni}$ concentrations. The heavy isotope enrichment of $\mathrm{Ni}$ from the leaves relative to the soils $\left(0.09 \pm 0.06 \%<<\Delta^{60} \mathrm{Ni}_{\text {leaves-soil }}<1.06 \pm 0.03 \%\right.$, Tab. 3$)$ suggests that the restitution and decomposition of this organic matter into topsoil will be accompanied by a supply of heavy labile Ni isotopes in the topsoil as measured in the DTPA solution. Zelano et al. (2018) observed that, during the degradation of leaves from hyperaccumulator plants, most of the Ni released had the same isotopic composition as the original leaves from Alyssum murale; for Rinorea bengalensis, during the first days of leaching, the Ni released in solution appeared to be isotopically heavy. However, this may 
contradict the results provided by Estrade et al. (2015) who reported that hyperaccumulators probably take up the lighter Ni fraction of the available heavy pool determined by DTPA, but that this fraction is still heavier than the total $\mathrm{Ni}$ in the soil.

The released $\mathrm{Ni}$ can then be sorbed and/or incorporated in the mineral or organic phases, as well as be taken up by plants or topsoil microorganisms. Assuming that Ni bound to organic matter in UM soil is more readily available than $\mathrm{Ni}$ bound to iron oxides, the heavy $\mathrm{Ni}$ isotope composition measured in the aerial parts of the plants may therefore be related to the heavy isotope signature of the DTPA extraction. The Ni contained in the DTPA solution would originate from the Ni initially complexed with the organic matter, resulting in a rapid cycling of heavy $\mathrm{Ni}$ isotopes at the soil surface. This remobilized Ni can also be leached down the soil profile to be sorbed deeper or discharged to surface or groundwaters. This progressive loss of heavy $\mathrm{Ni}$ in the surface horizons may explain the relatively light Ni isotope composition of Ni in the soils (Estrade et al., 2015; Ratié et al., 2015, 2016).

\section{Conclusions}

Ni hyperaccumulator plants (Justicia lanstyakii, Heliotropium aff. salicoides, Cnidoscolus aff. urens) and $\mathrm{Ni}$ accumulator plants (Manihot sp..) and their respective rhizospheric soils were collected at two UM sites in the Brazilian state of Goiás. The bioavailability of Ni for plants in rhizospheric soils, obtained by DTPA extraction, exhibits $\delta^{60} \mathrm{Ni}$ values ranging from $-0.30 \pm 0.05$ to $0.34 \pm 0.05 \%$ which can be used to identify an enrichment in heavy $\mathrm{Ni}$ isotopes in the DTPA-extractable Ni in topsoils ($0.31 \pm 0.10 \%_{0}<\Delta^{60} \mathrm{Ni}_{\text {soils-DTPA }}<-0.01 \pm 0.12 \%$ ) .

In both $\mathrm{Ni}$ hyperaccumulator and accumulator plants, the Ni concentrations exhibit a high content and large variability (up to $2.3 \mathrm{~g} \mathrm{~kg}^{-1}$ ). Likewise, their Ni isotope compositions show large variability ($0.47 \pm 0.08$ to $1.21 \pm 0.05 \%$ ) . Ni accumulator plants exhibit an enrichment in heavy $\mathrm{Ni}$ isotopes in the aerial parts, while the similar $\delta^{60} \mathrm{Ni}$ values for the roots, stems and aerial parts suggests that no significant fractionation occurs for the Ni hyperaccumulator plants during Ni uptake. However, two trends are identified between the various compartments induced by redistribution and transfer of $\mathrm{Ni}$ in 
plants: (1) the stems are more enriched in light $\mathrm{Ni}$ isotopes than the roots (Justicia lanstyakii: $\Delta^{60} \mathrm{Ni}_{\text {stems-roots }}=-0.02 \pm 0.19 \%$; Heliotropium aff. Salicoides: $\Delta^{60} \mathrm{Ni}_{\text {stems-roots }}=-0.22 \pm 0.19 \%$; Cnidoscolus aff. Urens: $\Delta^{60} \mathrm{Ni}_{\text {stems-roots }}=-0.17 \pm 0.13 \%$ ), while (2) the leaves are more enriched in heavy $\mathrm{Ni}$ isotopes than the stems (Justicia lanstyakii: $\Delta^{60} \mathrm{Ni}_{\text {leaves-stems }}=0.24 \pm 0.17 \%$; Heliotropium aff. Salicoides: $\Delta^{60} \mathrm{Ni}_{\text {leaves-stems }}=0.11 \pm 0.12 \%$; Cnidoscolus aff. Urens: $\Delta^{60} \mathrm{Ni}_{\text {leaves-stems }}=0.85 \pm 0.15 \%$ ).

In the laterite profile, the fractionation of $\mathrm{Ni}$ performed by plants and more especially the heavier $\mathrm{Ni}$ isotope composition in the leaves for all of the plants compared to the rhizospheric soil $(0.09 \pm 0.06 \%$ o $<\Delta^{60} \mathrm{Ni}_{\text {leaves-soil }}<1.06 \pm 0.03 \%$ ) may play a role in the overall isotopic $\mathrm{Ni}$ cycle. The input of heavy $\mathrm{Ni}$ litter falling onto the soil may gradually increase the heavy Ni isotope pool in the topsoil. Moreover, this pool is the first output of $\mathrm{Ni}$ in soils through lixiviation due to $\mathrm{Ni}$ recycling via litter degradation in the UM area.

All of these features highlight how complex it is to understand the role of plants in Ni biogeochemical cycling and indicates that the determination of the $\mathrm{Ni}$ isotope composition in these types of studies can help to identify and better quantify the biogeochemical cycle of metals in the soil-plant continuum. Our results also highlight the need to couple field studies with a laboratory approach with experiments under controlled conditions; hydroponic experiments may allow for the quantification of masses at the whole plant scale, on a larger number of specimens, and at different growth stages.

\section{Acknowledgments}

This work was financially supported by the French Ministry of National Education and Research (G. Ratié PhD grant), the National French Program EC2CO from INSU, CNRS, and a Marie Curie International Research Staff Exchange Scheme Fellowship within the 7th European Community Framework Programme (NIDYFICS, no. 318123) and CNPq universal 445423/2014-5, CNPq-PQ 310750/2014-8, FAP-DF 193.000.932/2015. This work was also possible through the Ciência Sem Fronteiras program (C. Quantin, PV: 406288/2015-1). The authors wish to thank Anglo American for access to their field facilities, the staff for their help during sampling and O. Rouxel (IFREMER, 
France) for preparing the Ni double spike. The authors would also like to thank the two reviewers for their comments and suggestions. Dr. S. Mullin is acknowledged for post-editing the English style (http://www.proz.com/profile/677614).

\section{References}

Albarede, F., \& Beard, B. (2004). Analytical methods for non-traditional isotopes. In C. M. Johnson, B. L. Beard, \& F. Albarede (Eds.), Geochemistry of Non-Traditional Stable Isotopes (Vol. 55, pp. 113-152).

Baker, A. J. M., \& Brooks, R. (1989). Terrestrial higher plants which hyperaccumulate metallic elements. A review of their distribution, ecology and phytochemistry. Biorecovery., $1(2), 81-126$.

Bani, A., Echevarria, G., Montargès-Pelletier, E., Gjoka, F., Sulçe, S., \& Morel, J. L. (2014). Pedogenesis and nickel biogeochemistry in a typical Albanian ultramafic toposequence. Environmental Monitoring and Assessment, 186(7), 4431-4442.

Becquer, T., Pétard, J., Duwig, C., Bourdon, E., Moreau, R., \& Herbillon, A. J. (2001). Mineralogical, chemical and charge properties of Geric Ferralsols from New Caledonia. Geoderma, 103(3-4), 291-306. http://doi.org/10.1016/S0016-7061(01)00045-3

Becquer, T., Quantin, C., \& Boudot, J. P. (2010). Toxic levels of metals in Ferralsols under natural vegetation and crops in New Caledonia. European Journal of Soil Science, 61(6), 994-1004. http://doi.org/10.1111/j.1365-2389.2010.01294.x

Bernal, M. P., McGrath, S. P., Miller, A. J., \& Baker, A. J. M. (1994). Comparison of the chemical changes in the rhizosphere of the nickel hyperaccumulator Alyssum murale with the non-accumulator Raphanus sativus. Plant and Soil, 164(2), 251-259.

Briat, J.-F., \& Lebrun, M. (1999). Plant responses to metal toxicity. Comptes Rendus de l'Académie Des Sciences-Series III-Sciences de La Vie, 322(1), 43-54.

Brooks, R. R., Morrison, R. S., Reeves, R. D., Dudley, T. R., \& Akman, Y. (1979). Hyperaccumulation of nickel by Alyssum linnaeus (Cruciferae). Proc. R. Soc. Lond. B, 203(1153), 387-403.

Buffle, J. (1988). Complexation reactions in aquatic systems. An analytical approach.

Bullen, T. D. (2014). 7.10 - Metal Stable Isotopes in Weathering and Hydrology. In H. D. Holland \& K. K. Turekian (Eds.), Treatise on Geochemistry (Second Edition) (pp. 329-359). Oxford: Elsevier. Retrieved from http://www.sciencedirect.com/science/article/pii/B9780080959757005118 
Cameron, V., Vance, D., Archer, C., \& House, C. H. (2009). A biomarker based on the stable isotopes of nickel. Proceedings of the National Academy of Sciences, 106(27), 10944-10948.

Centofanti, T., Siebecker, M. G., Chaney, R. L., Davis, A. P., \& Sparks, D. L. (2012). Hyperaccumulation of nickel by Alyssum corsicum is related to solubility of $\mathrm{Ni}$ mineral species. Plant and Soil, 359(1-2), 71-83.

Centofanti, T., Sayers, Z., Cabello-Conejo, M. I., Kidd, P., Nishizawa, N. K., Kakei, Y., Davis, A. K., Sicher, R. C., \& Chaney, R. L. (2013). Xylem exudate composition and root-toshoot nickel translocation in Alyssum species. Plant and Soil, 373(1-2), 59-75.

Chardot, V., Massoura, S. T., Echevarria, G., Reeves, R. D., \& Morel, J.-L. (2005). Phytoextraction Potential of the Nickel Hyperaccumulators Leptoplax emarginata and Bornmuellera tymphaea. International Journal of Phytoremediation, 7(4), 323-335. http://doi.org/10.1080/16226510500327186

Chardot-Jacques, V., Calvaruso, C., Simon, B., Turpault, M.-P., Echevarria, G., \& Morel, J.L. (2013). Chrysotile Dissolution in the Rhizosphere of the Nickel Hyperaccumulator Leptoplax emarginata. Environmental Science \& Technology, 47(6), 2612-2620. http://doi.org/10.1021/es301229m

Deng, T.-H.-B., Coquet, C., Tang, Y.-T., Sterckeman, T., Echevarria, G., Estrade, N., Morel, J.-L., \& Qiu, R.-L. (2014). Nickel and Zinc Isotope Fractionation in Hyperaccumulating and Nonaccumulating Plants. Environmental Science \& Technology, 48(20), 11926-11933. http://doi.org/10.1021/es5020955

Deng, T.-H.-B., van der Ent, A., Tang, Y.-T., Sterckeman, T., Echevarria, G., Morel, J.-L., \& Qiu, R.-L. (2018). Nickel hyperaccumulation mechanisms: a review on the current state of knowledge. Plant and Soil, 423(1), 1-11. http://doi.org/10.1007/s11104-017-3539-8

Echevarria, G., Morel, J. L., Fardeau, J. C., \& Leclerc-Cessac, E. (1998). Assessment of phytoavailability of nickel in soils. Journal of Environmental Quality, 27(5), 1064-1070.

Echevarria, G., Massoura, S. T., Sterckeman, T., Becquer, T., Schwartz, C., \& Morel, J. L. (2006). Assessment and control of the bioavailability of nickel in soils. Environmental Toxicology and Chemistry, 25(3), 643-651.

Echevarria, G. (2018). Genesis and behaviour of ultramafic soils and consequences for nickel biogeochemistry. In Agromining: Farming for Metals (pp. 135-156). Springer.

Estrade, N., Cloquet, C., Echevarria, G., Sterckeman, T., Deng, T., Tang, Y., \& Morel, J.-L. (2015). Weathering and vegetation controls on nickel isotope fractionation in surface ultramafic environments (Albania). Earth and Planetary Science Letters, 423(0), 24-35. http://doi.org/10.1016/j.eps1.2015.04.018

Gall, L., Williams, H. M., Halliday, A. N., \& Kerr, A. C. (2017). Nickel isotopic composition of the mantle. Geochimica et Cosmochimica Acta, 199, 196-209. http://doi.org/10.1016/j.gca.2016.11.016 
Garnier, J., Quantin, C., Martins, E. S., \& Becquer, T. (2006). Solid speciation and availability of chromium in ultramafic soils from Niquelândia, Brazil. Journal of Geochemical Exploration, 88(1-3), 206-209.

Garnier, J., Quantin, C., Guimaraes, E., Garg, V. K., Martins, E. S., \& Becquer, T. (2009). Understanding the genesis of ultramafic soils and catena dynamics in Niquelandia, Brazil. Geoderma, 151(3-4), 204-214. http://doi.org/10.1016/j.geoderma.2009.04.020

Gramlich, J. W., Machlan, L., Barnes, I. L., \& Paulsen, P. J. (1989). Absolute isotopic abundance ratios and atomic weight of a reference sample of nickel. Journal of Research of the National Institute of Standards and Technology, 94(6), 347-356.

Gueguen, B., Rouxel, O., Ponzevera, E., Bekker, A., \& Fouquet, Y. (2013). Nickel Isotope Variations in Terrestrial Silicate Rocks and Geological Reference Materials Measured by MC-ICP-MS. Geostandards and Geoanalytical Research, 37(3), 297-317.

Jaffré, T., Brooks, R., Lee, J., \& Reeves, R. (1976). Sebertia acuminata: a hyperaccumulator of nickel from New Caledonia. Science, 193(4253), 579-580.

Kukier, U., \& Chaney, R. L. (2001). Amelioration of nickel phytotoxicity in muck and mineral soils. Journal of Environmental Quality, 30(6), 1949-1960.

Lee, J., Reeves, R. D., Brooks, R. R., \& Jaffré, T. (1977). Isolation and identification of a citrato-complex of nickel from nickel-accumulating plants. Phytochemistry, 16(10), 15031505 .

L'Huillier, L., \& Edighoffer, S. (1996). Extractability of nickel and its concentration in cultivated plants in Ni rich ultramafic soils of New Caledonia. Plant and Soil, 186(2), 255264. http://doi.org/10.1007/BF02415521

Massoura, S. T., Echevarria, G., Leclerc-Cessac, E., \& Morel, J. L. (2005). Response of excluder, indicator, and hyperaccumulator plants to nickel availability in soils. Soil Research, 42(8), 933-938.

Massoura, S. T., Echevarria, G., Becquer, T., Ghanbaja, J., Leclere-Cessac, E., \& Morel, J.-L. (2006). Control of nickel availability by nickel bearing minerals in natural and anthropogenic soils. Geoderma, 136(1-2), 28-37. http://doi.org/10.1016/j.geoderma.2006.01.008

McCarthy, J., \& Zachara, J. (1989). ES\&T Features: Subsurface transport of contaminants. Environmental Science \& Technology, 23(5), 496-502.

McGrath, S. P., Shen, Z. G., \& Zhao, F. J. (1997). Heavy metal uptake and chemical changes in the rhizosphere of Thlaspi caerulescens and Thlaspi ochroleucum grown in contaminated soils. Plant and Soil, 188(1), 153-159.

Mesjasz-Przybyłowicz, J., Nakonieczny, M., Migula, P., Augustyniak, M., Tarnawska, M., Reimold, W., Koeberl, C., Przybyłowicz, W., \& Głowacka, E. (2004). Uptake of cadmium, 
lead nickel and zinc from soil and water solutions by the nickel hyperaccumulator Berkheya coddii. Acta Biol Cracov Ser Bot, 46, 75-85.

Minguzzi, C., \& Vergnano, O. (1948). Il contenuto di nichel nelle ceneri di Alyssum bertolonii Desv. Mem. Soc. Tosc. Sci. Nat. Ser. A, 55, 49-77.

Moynier, F., Blichert-Toft, J., Telouk, P., Luck, J.-M., \& Albarède, F. (2007). Comparative stable isotope geochemistry of $\mathrm{Ni}, \mathrm{Cu}, \mathrm{Zn}$, and $\mathrm{Fe}$ in chondrites and iron meteorites. $\begin{array}{llll}\text { Geochimica et } \quad \text { Cosmochimica } & \text { 41(17), }\end{array}$ http://doi.org/10.1016/j.gca.2007.06.049

Pędziwiatr, A., Kierczak, J., Waroszewski, J., Ratié, G., Quantin, C., \& Ponzevera, E. (2018). Rock-type control of $\mathrm{Ni}, \mathrm{Cr}$, and Co phytoavailability in ultramafic soils. Plant and Soil, 423(1-2), 339-362.

Perrier, N., Amir, H., \& Colin, F. (2006). Occurrence of mycorrhizal symbioses in the metalrich lateritic soils of the Koniambo Massif, New Caledonia. Mycorrhiza, 16(7), 449-458.

Proctor, J., \& Woodell, S. R. (1975). The ecology of serpentine soils. Advances in Ecological Research, 9, 255-366.

Puschenreiter, M., Wieczorek, S., Horak, O., \& Wenzel, W. W. (2003). Chemical changes in the rhizosphere of metal hyperaccumulator and excluder Thlaspi species. Journal of Plant Nutrition and Soil Science, 166(5), 579-584.

Puschenreiter, M., Schnepf, A., Millán, I. M., Fitz, W. J., Horak, O., Klepp, J., Schrefl, T., Lombi, E., \& Wenzel, W. W. (2005). Changes of Ni biogeochemistry in the rhizosphere of the hyperaccumulator Thlaspi goesingense. Plant and Soil, 271(1), 205-218.

Quantin, C., Ettler, V., Garnier, J., \& Šebek, O. (2008). Sources and extractibility of chromium and nickel in soil profiles developed on Czech serpentinites. Comptes Rendus Geoscience, 340(12), 872-882.

Quitté, G., \& Oberli, F. (2006). Quantitative extraction and high precision isotope measurements of nickel by MC-ICPMS. Journal of Analytical Atomic Spectrometry, 21(11), $1249-1255$.

Raous, S. (2008). Levantamento Preliminar de Espécies Vegetais Tolerantes ao Níquel, Niquelândia, GO.

Ratié, G., Jouvin, D., Garnier, J., Rouxel, O., Miska, S., Guimarães, E., Cruz Viera, L., Sivry, Y., Zelano, I., Montargès-Pelletier, E., Thil, F., \& Quantin, C. (2015). Nickel isotope fractionation during tropical weathering of ultramafic rocks. Chemical Geology, 402(0), 6876. http://doi.org/10.1016/j.chemgeo.2015.02.039

Ratié, G., Quantin, C., Jouvin, D., Calmels, D., Ettler, V., Sivry, Y., Cruz Vieira, L., Ponzevera, E., \& Garnier, J. (2016). Nickel isotope fractionation during laterite Ni ore 
smelting and refining: Implications for tracing the sources of $\mathrm{Ni}$ in smelter-affected soils. Applied Geochemistry, 64, 136-145.

Ratié, G., Garnier, J., Calmels, D., Vantelon, D., Guimarães, E., Monvoisin, G., Nouet, J., Ponzevera, E., \& Quantin, C. (2018). Nickel distribution and isotopic fractionation in a Brazilian lateritic regolith: Coupling Ni isotopes and Ni K-edge XANES. Geochimica et Cosmochimica Acta, 230, 137-154.

Reeves, R. D., Brooks, R. R., \& Dudley, T. R. (1983). Uptake of nickel by species of Alyssum, Bornmuellera, and other genera. Taxon, 32(2), 184-192. http://doi.org/10.2307/1221970

Reeves, R. D., Baker, A. J. M., Borhidi, A., \& Berazain, R. (1996). Nickel accumulating plants from the ancient serpentine soils of Cuba. New Phytologist, 133(2), 217-224. http://doi.org/10.1111/j.1469-8137.1996.tb01888.x

Reeves, R. D., Baker, A. J. M., Borhidi, A., \& Berazain, R. (1999). Nickel hyperaccumulation in the serpentine flora of Cuba. Annals of Botany, 83(1), 29-38. http://doi.org/10.1006/anbo.1998.0786

Reeves, R. D. (2003). Tropical hyperaccumulators of metals and their potential for phytoextraction. Plant and Soil, 249(1), 57-65.

Reeves, R. D., Baker, A. J. M., Becquer, T., Echevarria, G., \& Miranda, Z. J. G. (2007). The flora and biogeochemistry of the ultramafic soils of Goias state, Brazil. Plant and Soil, 293(12), 107-119. http://doi.org/10.1007/s11104-007-9192-x

Reeves, R. D., Baker, A. J., Jaffré, T., Erskine, P. D., Echevarria, G., \& van der Ent, A. (2018). A global database for plants that hyperaccumulate metal and metalloid trace elements. New Phytologist, 218(2), 407-411.

Saar, R. A., \& Weber, J. H. (1982). Fulvic acid: modifier of metal-ion chemistry. Environmental Science \& Technology, 16(9), 510A-517A.

Siebert, C., Nagler, T. F., \& Kramers, J. D. (2001). Determination of molybdenum isotope fractionation by double-spike multicollector inductively coupled plasma mass spectrometry. Geochemistry Geophysics Geosystems, 2, art. no.-2000GC000124.

Tang, Y.-T., van der Ent, A., Sterckeman, T., Echevarria, G., Morel, J.-L., \& Qiu, R.-L. (2016). Nickel translocation via the phloem in the hyperaccumulator Noccaea caerulescens (Brassicaceae). Plant and Soil, 404(1-2), 35-45.

Van der Ent, A., Baker, A. J. M., Reeves, R. D., pollard, A. J., \& Schat, H. (2013). Hyperaccumulators of metal and metalloid trace elements: Facts and fiction. Plant and Soil, 362(1-2), 319-334. http://doi.org/10.1007/s11104-012-1287-3 
Van der Ent, A., Baker, A. J., Reeves, R. D., Chaney, R. L., Anderson, C. W., Meech, J. A., Erskine, P. D., Simonnot, M.-O., Vaughan, J., \& Morel, J. L. (2015). Agromining: farming for metals in the future? ACS Publications.

Van der Ent, A., Tang, Y.-T., Sterckeman, T., Echevarria, G., Morel, J.-L., \& Qiu, R.-L. (2017). Nickel hyperaccumulation mechanisms: a review on the current state of knowledge. Plant and Soil, 1-11.

Van der Ent, A., Cardace, D., Tibbett, M., \& Echevarria, G. (2018). Ecological implications of pedogenesis and geochemistry of ultramafic soils in Kinabalu Park (Malaysia). Catena, $160,154-169$.

Walker, R. B. (1954). The ecology of serpentine soils. 2. Factors affecting plant growth on serpentine soils. Ecology, 35(2), 259-266.

Weiss, D. J., Rehkamper, M., Schoenberg, R., McLaughlin, M., Kirby, J., Campbell, P. G. C., Arnold, T., Chapman, J., Peel, K., \& Gioia, S. (2008). Application of nontraditional stableisotope systems to the study of sources and fate of metals in the environment. Environmental Science \& Technology, 42(3). http://doi.org/10.1021/es0870855

Welch, R. M. (1981). The biological significance of nickel. Journal of Plant Nutrition, 3(14), 345-356.

Wenzel, W. W., Bunkowski, M., Puschenreiter, M., \& Horak, O. (2003). Rhizosphere characteristics of indigenously growing nickel hyperaccumulator and excluder plants on serpentine soil. Environmental Pollution, 123(1), 131-138.

Whittaker, R. H. (1954). The ecology of serpentine soils. Ecology, 258-288.

Wiederhold, J. G. (2015). Metal Stable Isotope Signatures as Tracers in Environmental Geochemistry. Environmental Science \& Technology, 49(5), 2606-2624. http://doi.org/10.1021/es504683e

Zelano, I. O., Cloquet, C., Fraysse, F., Dong, S., Janot, N., Echevarria, G., \& MontargèsPelletier, E. (2018). The influence of organic complexation on $\mathrm{Ni}$ isotopic fractionation and $\mathrm{Ni}$ recycling in the upper soil layers. Chemical Geology, 483, 47-55. http://doi.org/10.1016/j.chemgeo.2018.02.023

Zhao, F. J., Hamon, R. E., \& McLaughlin, M. J. (2001). Root exudates of the hyperaccumulator Thlaspi caerulescens do not enhance metal mobilization. New Phytologist, 151(3), 613-620. 


\section{Table captions}

Table 1: Chemical (K, Ca, Mg, Al, Fe, Mn, Ni, $\mathrm{N}_{\text {org }}$ and $\mathrm{OC}$ ) and isotopic composition ( $\mathrm{N}, \mathrm{C}$ and $\mathrm{Ni}$ ) of topsoils collected in Barro Alto and Niquelândia. Sample color was determined according to the Munsell chart. Localization (UM BA: in the UM Barro Alto complex, UM Niq: in the UM Niquelândia complex). DTPA extraction was performed with measurement of Ni content extracted by DTPA and its Ni isotope composition. * published names used in Ratié et al. 2016. n.d.: not determined.

Table 2: Chemical and $\mathrm{Ni}$ isotopic composition of plant samples. For each specimen, chemical composition of topsoil and its Ni DTPA extract were given. Jus: Justicia Lanstyakii, Hel : Heliotropium aff. Salicoide, Cni : Cnidoscolus aff. Urens, Man : Manihot sp., * sampled in UM site of Barro Alto, ** sampled in UM site of Niquelândia.

Table 3: Table 2: $\Delta^{60} \mathrm{Ni}(\%)$ calculated with the $\delta^{60} \mathrm{Ni}$ mean value for each part of plant. Jus: Justicia Lanstyakii, Hel: Heliotropium aff. salicoide, Cni: Cnidoscolus aff. urens, Man: Manihot sp. Mean SD values have been calculated: $\frac{1}{n} \sum 2 \sigma$. Hyp: Ni-hyperaccumulator, Acc: Ni-accumulator. 


\begin{tabular}{|c|c|c|c|c|c|c|c|c|c|c|c|c|c|c|c|c|c|c|c|c|}
\hline \multirow{4}{*}{$\begin{array}{c}\begin{array}{c}\text { Sample } \\
\text { name }\end{array} \\
\text { BA_S1* }\end{array}$} & \multirow{4}{*}{$\begin{array}{c}\begin{array}{c}\text { Sample } \\
\text { color }\end{array} \\
2,5 \text { YR } 2,5 / 3\end{array}$} & \multirow{4}{*}{$\begin{array}{c}\text { Localization } \\
\text { UM BA }\end{array}$} & \multicolumn{15}{|c|}{ Total } & \multicolumn{3}{|c|}{ DTPA extraction } \\
\hline & & & $\mathbf{K}$ & $\mathrm{Ca}$ & Mg & Al & $\mathrm{Fe}$ & $\mathrm{Mn}$ & $\mathrm{Ni}$ & $N_{\text {tot }}$ & OC & \multirow{3}{*}{$\begin{array}{l}\mathrm{pH} \\
5.9\end{array}$} & \multirow{3}{*}{$\begin{array}{c}\Delta \mathrm{pH} \\
\mathrm{pH}_{\mathrm{KCl}}-\mathrm{pH}_{\mathrm{w}} \\
-0.76\end{array}$} & $\delta^{15} \mathrm{~N}$ & $\delta^{13} \mathrm{C}$ & $\delta^{60} \mathrm{Ni}$ & 2SD & \multirow{2}{*}{$\begin{array}{c}\text { Ni DTPA } \\
\mathrm{mg} / \mathrm{kg}\end{array}$} & \multirow{2}{*}{\multicolumn{2}{|c|}{$\frac{\delta^{60} \mathrm{Ni} \quad 2 \mathrm{SD}}{\%}$}} \\
\hline & & & \multicolumn{7}{|c|}{$\mathrm{g} / \mathrm{kg}$} & \multicolumn{2}{|c|}{$\%$} & & & \multicolumn{4}{|c|}{$\%$} & & & \\
\hline & & & 0.1 & 4.2 & 24.9 & 24.6 & 290.8 & 5.2 & 12.8 & 0.26 & 3.82 & & & 7.52 & -17.93 & -0.09 & 0.05 & 623 & n.d. & n.d. \\
\hline BA_S2* & $2,5 Y R 2,5 / 3$ & UM BA & 0.1 & 3.7 & 16.9 & 26.2 & 298.5 & 5.1 & 10.8 & 0.26 & 3.58 & 6.1 & -0.72 & 7.60 & -18.64 & -0.19 & 0.05 & 444 & n.d. & n.d. \\
\hline BA_S3* & $2,5 Y R 2,5 / 2$ & UM BA & 0.2 & 6.4 & 19.0 & 42.4 & 318.3 & 5.2 & 9.8 & n.d & n.d & 5.9 & -0.42 & n.d & n.d & S.I. & 0.05 & n.d. & n.d. & n.d. \\
\hline BA_S4* & $2,5 Y R 2,5 / 3$ & UM BA & 0.2 & 4.5 & 20.0 & 44.0 & 307.4 & 5.0 & 9.9 & 0.19 & 2.63 & 6.2 & -0.74 & 5.95 & -16.30 & -0.16 & 0.05 & 220 & -0.13 & 0.14 \\
\hline BA_S5* & $2,5 Y R 3 / 2$ & UM BA & 0.2 & 0.5 & 6.4 & 35.3 & 336.2 & 5.2 & 7.5 & 0.33 & 5.40 & 6.3 & -1.28 & 4.95 & & -0.10 & 0.08 & 206 & -0.06 & 0.05 \\
\hline BA_S6* & $2,5 Y R 3 / 3$ & UM BA & 0.1 & 0.3 & 4.3 & 34.6 & 357.3 & 6.3 & 7.6 & 0.24 & 3.82 & 6.2 & -1.23 & 6.41 & -16.75 & -0.14 & 0.05 & 117 & -0.21 & 0.05 \\
\hline BA_S7* & $2,5 Y R 2,5 / 3$ & UM BA & 0.1 & 0.1 & 1.5 & 35.2 & 390.3 & 5.2 & 4.3 & 0.21 & 3.61 & 6 & 11 & 0.44 & -17.65 & 0.10 & 0.05 & 14 & -0.08 & 0.08 \\
\hline BA_S8* & 10R $3 / 2$ & UM BA & 0.2 & 0.1 & 1.2 & 32.9 & 278.3 & 3.8 & 3.3 & 0.21 & 3.59 & 6.3 & 1.04 & 4.98 & -19.20 & 0.11 & 0.10 & 16 & -0.06 & 0.06 \\
\hline BA_S9* & $2,5 Y R 2,5 / 3$ & UM BA & 0.2 & 5.8 & 16.6 & 37.5 & 347.2 & 5.1 & 10.4 & 0.18 & 2.41 & 68 & & 5.47 & -15.92 & -0.20 & 0.13 & 181 & -0.05 & 0.06 \\
\hline BA_S10* & $2,5 Y R 3 / 4$ & UM BA & 0.2 & 2.8 & 14.6 & 36.8 & 314.5 & 4.3 & 9.2 & 0.22 & 3.16 & 6.5 & -1.23 & 5.63 & -17.86 & -0.09 & 0.08 & 260 & -0.03 & 0.05 \\
\hline BA_S11* & $5 Y R 2,5 / 3$ & UM BA & 0.2 & 8.2 & 20.4 & 33.5 & 356.0 & 5.8 & 10.7 & 0.18 & 2.04 & & n.d & 4.30 & -17.04 & -0.26 & 0.09 & 191 & -0.30 & 0.05 \\
\hline BA_S12* & $2,5 Y R 2,5 / 3$ & UM BA & 0.1 & 4.6 & 22.9 & 36.3 & 509.6 & 7.0 & 14.2 & 0.16 & 2.28 & & n.d & 5.78 & -16.04 & -0.17 & 0.05 & 124 & -0.02 & 0.05 \\
\hline BA_S13* & $2,5 Y R 3 / 4$ & UM BA & 0.2 & 8.4 & 24.7 & 30.2 & 410.6 & 7.1 & 13.7 & 0.17 & 2.28 & & n.d & 6.16 & -15.63 & -0.30 & 0.06 & 198 & -0.27 & 0.05 \\
\hline NQ_S1* & $10 \mathrm{R} 3 / 3$ & UM Niq & 0.1 & 0.7 & 22.8 & 23.9 & 364.8 & 6.8 & 9.2 & 0.17 & 2.73 & 6 & -0.88 & 6.01 & -23.32 & -0.07 & 0.05 & 301 & n.d. & n.d. \\
\hline NQ_S2* & 10R $3 / 4$ & UM Niq & 0.1 & 0.4 & 14.9 & 22.3 & 459.7 & 7.9 & 10.1 & 0.16 & 2.47 & 6.3 & -1.22 & 5.08 & -25.65 & -0.06 & 0.05 & 269 & 0.05 & 0.05 \\
\hline NQ_S3* & $10 R 3 / 3$ & UM Niq & 0.1 & 0.4 & 16.1 & 19.2 & 457.4 & 7.7 & 9.4 & 0.08 & 1.61 & 6.5 & -1.08 & 5.22 & -24.09 & -0.09 & 0.05 & 94 & 0.23 & 0.08 \\
\hline NQ_S4* & 10R $2,5 / 2$ & UM Niq & 0.1 & 0.3 & 16.5 & 21.9 & 517.4 & 9.5 & 12.2 & 0.17 & 2.70 & 6.1 & -0.9 & 5.21 & -25.07 & -0.05 & 0.14 & 186 & 0.07 & 0.06 \\
\hline NQ_S9 & $10 \mathrm{R} 3 / 4$ & UM Niq & 0.1 & 0.7 & 24.3 & 13.9 & 513.2 & 8.1 & 16.9 & n.d & n.d & 6.5 & -0.95 & n.d & n.d & 0.15 & 0.05 & 293 & 0.34 & 0.05 \\
\hline NQ_S10 & 5YR $5 / 6$ & UM Niq & 0.1 & 1.4 & 24.8 & 16.4 & 343.5 & 6.5 & 11.8 & n.d & n.d & 6.6 & -0.68 & n.d & n.d & 0.16 & 0.05 & 412 & 0.34 & 0.06 \\
\hline
\end{tabular}

Table 1 


\begin{tabular}{|c|c|c|c|c|c|c|c|c|c|c|c|c|c|c|c|c|c|c|}
\hline \multirow{2}{*}{ Name } & \multirow{2}{*}{ Type } & $\mathrm{Ca}$ & $\mathrm{K}$ & $\mathrm{Mg}$ & $\mathrm{Na}$ & $\mathrm{Fe}$ & $\mathrm{Ni}$ & $\delta^{60} \mathrm{Ni}$ & 2 S.D. & & $\delta^{60} \mathrm{Ni}$ & 2 S.D. & & & nslocat & on Fac & & \\
\hline & & & & & & & & & & & & & $\mathrm{Ca}$ & $\mathrm{K}$ & $\mathrm{Mg}$ & $\mathrm{Na}$ & $\mathrm{Fe}$ & $\mathrm{Ni}$ \\
\hline & BA_S11 & 8231 & 180 & 20423 & 392 & 356000 & 10700 & -0.26 & 0.09 & 192 & -0.30 & 0.05 & & & & & & \\
\hline lus $1 *$ & Roots & 1535 & 1339 & 2199 & 162 & 422 & 368 & -0.47 & 0.08 & & & & 8.8 & 13.7 & 11.1 & 1.3 & 6.2 & 3.4 \\
\hline Jus1" & Stems & 3840 & 11327 & 2197 & 224 & 953 & 666 & -0.44 & 0.07 & & & & & & & & & \\
\hline & Leaves & 13465 & 18300 & 24500 & 214 & 2604 & 1239 & -0.25 & 0.07 & & & & & & & & & \\
\hline & BA_S12 & 4599 & 145 & 22942 & 293 & 509597 & 14159 & -0.17 & 0.05 & 124 & -0.03 & 0.07 & & & & & & \\
\hline Jus?* & Roots & 2727 & 2893 & 2524 & 222 & 524 & 723 & -0.21 & 0.09 & & & & 6.6 & 3.4 & 13.2 & 0.7 & 5.1 & 0.8 \\
\hline Jusz" & Stems & 1984 & 14196 & 2327 & 171 & 533 & 369 & -0.15 & 0.09 & & & & & & & & & \\
\hline & Leaves & 17999 & 9766 & 33434 & 166 & 2661 & 602 & 0.03 & 0.07 & & & & & & & & & \\
\hline & BA_S13 & 8424 & 158 & 24689 & 411 & 410590 & 13719 & -0.30 & 0.06 & 198 & -0.27 & 0.05 & & & & & & \\
\hline lus $3 *$ & Roots & 919 & 1201 & 2087 & 182 & 663 & 418 & -0.45 & 0.06 & & & & 12.5 & 22.5 & 3.7 & 1.4 & 1.6 & 5.5 \\
\hline Juss" & Stems & 2163 & 5998 & 2357 & 267 & 1563 & 691 & -0.40 & 0.05 & & & & & & & & & \\
\hline & Leaves & 11495 & 27080 & 7745 & 260 & 1051 & 2309 & -0.16 & 0.05 & & & & & & & & & \\
\hline & BA_S1 & 4201 & 125 & 24923 & 273 & 290819 & 12798 & -0.09 & 0.05 & 623 & n.d. & n.d. & & & & & & \\
\hline & Roots & 1630 & 4998 & 4058 & 430 & 3760 & 814 & 0.03 & 0.11 & & & & 8.5 & 2.2 & 6.7 & 1.0 & 0.2 & 2.7 \\
\hline Jus4* & Stems & 2149 & 7988 & 2675 & 452 & 377 & 505 & -0.19 & 0.05 & & & & & & & & & \\
\hline & Leaves & 13935 & 10766 & 27080 & 441 & 898 & 2213 & 0.16 & 0.05 & & & & & & & & & \\
\hline & Flowers & 6387 & 28080 & 8462 & 81 & 3175 & 276 & -0.16 & 0.08 & & & & & & & & & \\
\hline & BA_S6 & 289 & 99 & 4308 & 40 & 357324 & 7589 & -0.14 & 0.05 & 117 & $\begin{array}{l}-0.21 \\
\end{array}$ & 0.05 & & & & & & \\
\hline & Roots & 3356 & 1493 & 4997 & 182 & 264 & 542 & 0.01 & 0.07 & & & & 18.0 & 4.6 & 1.5 & 0.9 & 1.8 & 2.3 \\
\hline Hel1* & Stems & 5095 & 3799 & 2871 & 156 & 214 & 459 & -0.18 & 0.15 & & & & & & & & & \\
\hline & Leaves & 60561 & 6872 & 7425 & 157 & 474 & 1272 & -0.02 & 0.12 & & & & & & & & & \\
\hline & Flowers & 41547 & 8060 & 6080 & 220 & 210 & 2668 & 0.49 & 0.2 & & & & & & & & & \\
\hline & BA_S9 & 5796 & 146 & 16631 & 321 & 347163 & 10430 & -0.20 & 0.13 & 181 & -0.05 & 0.06 & & & & & & \\
\hline & Roots & 2566 & 4117 & 4909 & 244 & 294 & 295 & -0.01 & 0.05 & & & & 17.2 & 1.1 & 2.3 & 0.7 & 5.3 & 8.1 \\
\hline Hel2* & Stems & 15494 & 5600 & 5031 & 155 & 2147 & 841 & -0.26 & 0.05 & & & & & & & & & \\
\hline & Leaves & 44108 & 4409 & 11396 & 161 & 1544 & 2381 & 0.02 & 0.05 & & & & & & & & & \\
\hline & Flowers & 35383 & 1342 & 9594 & 126 & 467 & 407 & -0.25 & 0.05 & & & & & & & & & \\
\hline & BA_S1 & 4201 & 125 & 24923 & 273 & 290819 & 12798 & -0.09 & 0.05 & 623 & n.d. & n.d. & & & & & & \\
\hline & Roots & 2744 & 7343 & 2612 & 84 & 1995 & 371 & -0.12 & 0.05 & & & & 18.9 & 1.4 & 2.7 & 0.9 & 0.8 & 2.2 \\
\hline Hel3* & Stems & 9798 & 6595 & 2953 & 79 & 2389 & 337 & -0.13 & 0.05 & & & & & & & & & \\
\hline & Leaves & 51871 & 10327 & 7099 & 79 & 1522 & 800 & -0.08 & 0.05 & & & & & & & & & \\
\hline & Flowers & 57630 & 10676 & 6741 & 80 & 1034 & 385 & -0.02 & 0.05 & & & & & & & & & \\
\hline & BA_S4 & 4532 & 196 & 20029 & 193 & 307363 & 9848 & $\begin{array}{l}-0.16 \\
\end{array}$ & 0.05 & 217 & $\begin{array}{l}-0.13 \\
\end{array}$ & 0.14 & & & & & & \\
\hline Hela* & Stems & 12960 & 7087 & 3544 & 75 & 494 & 432 & -0.36 & 0.06 & & & & n.d. & n.d. & n.d. & n.d. & n.d. & n.d. \\
\hline Hel4* & Leaves & 55006 & 11559 & 11875 & 90 & 1446 & 946 & -0.13 & 0.05 & & & & & & & & & \\
\hline & Flowers & 53990 & 8629 & 10518 & 77 & 752 & 455 & -0.17 & 0.05 & & & & & & & & & \\
\hline & NQ_S2 & 457 & 127 & 14939 & 36 & 459661 & 10074 & -0.06 & 0.05 & 269 & 0.05 & 0.05 & & & & & & \\
\hline & Roots & 1728 & 1771 & 3113 & 142 & 257 & 1375 & 0.43 & 0.06 & & & & 18.5 & 1.9 & 5.0 & 1.1 & 7.0 & 1.7 \\
\hline Hel5** & Stems & 4897 & 2865 & 6639 & 160 & 399 & 1626 & 0.14 & 0.08 & & & & & & & & & \\
\hline & Leaves & 31968 & 3296 & 15445 & 162 & 1791 & 2316 & 0.02 & 0.1 & & & & & & & & & \\
\hline & Flowers & 30213 & 12974 & 14053 & 204 & 464 & 594 & -0.11 & 0.11 & & & & & & & & & \\
\hline & NQ_S4 & 324 & 116 & 16470 & 28 & 517380 & 12242 & -0.05 & 0.14 & 186 & 0.07 & 0.06 & & & & & & \\
\hline Hel6** & Roots & 1518 & 2170 & n.d. & 120 & 664 & 118 & 0.06 & 0.07 & & & & 24.9 & 1.5 & & 1.3 & 6.1 & 8.1 \\
\hline Helb" & Stems & 6277 & 2865 & 4295 & 152 & 1153 & 164 & -0.06 & 0.1 & & & & & & & & & \\
\hline & Leaves & 37795 & 3229 & 17980 & 160 & 4038 & 959 & 0.01 & 0.07 & & & & & & & & & \\
\hline & NQ_S9 & 719 & 87 & 24309 & 43 & 513204 & 16873 & 0.15 & 0.05 & 292 & 0.22 & 0.12 & & & & & & \\
\hline Cin $*$ & Roots & 2896 & 6890 & 4816 & 154 & 221 & 325 & 0.55 & 0.07 & & & & n.d. & n.d. & n.d. & n.d. & n.d. & n.d. \\
\hline $\operatorname{cnil}^{*}$ & Stems & 11725 & 4419 & 15069 & 135 & 133 & 429 & 0.63 & 0.1 & & & & & & & & & \\
\hline & Flowers & 11842 & 11106 & 4892 & 137 & 2195 & 1511 & 0.47 & 0.05 & & & & & & & & & \\
\hline & NQ_S9 & 719 & 87 & 24309 & 43 & 513204 & 16873 & 0.15 & 0.05 & 292 & 0.34 & 0.05 & & & & & & \\
\hline Cnin* & Roots & 1593 & 7503 & 2125 & 145 & 136 & 135 & 0.52 & 0.05 & & & & n.d. & n.d. & n.d. & n.d. & n.d. & n.d. \\
\hline Cni2* & Stems & 2716 & 5266 & 6114 & 136 & 302 & 41 & 0.14 & 0.05 & & & & & & & & & \\
\hline & Flowers & 11464 & 9899 & 8633 & 152 & 964 & 445 & 0.32 & 0.09 & & & & & & & & & \\
\hline & NQ_S10 & 1382 & 89 & 24831 & 1 & 343511 & 11775 & 0.16 & 0.06 & 412 & 0.34 & 0.06 & & & & & & \\
\hline Cni3* & Stems & 6019 & 17405 & 6736 & 188 & 77 & 239 & 0.32 & 0.05 & & & & n.d. & n.d. & n.d. & n.d. & n.d. & n.d. \\
\hline & Leaves & 10472 & 1372 & 5564 & 443 & 467 & 311 & 1.21 & 0.05 & & & & & & & & & \\
\hline & "BA_S1 & 44201 & 125 & 24923 & $\overline{27273}$ & 290819 & $\bar{~} 12798$ & "-0.09 & 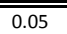 & $\bar{~} 623$ & $\overline{~ n . d . ~}$ & $\overline{\overline{\text { n.d. }}}$ & & & & & & \\
\hline Man1* & Roots & 3322 & 3798 & 4272 & 125 & 147 & 295 & 0.16 & 0.06 & & & & 1.7 & 3.1 & 1.0 & 0.6 & 9.6 & 0.6 \\
\hline Mian1* & Stems & 9791 & 6816 & 3337 & 77 & 180 & 338 & 0.17 & 0.08 & & & & & & & & & \\
\hline & Leaves & 5560 & 11625 & 4085 & 72 & 1415 & 178 & 0.37 & 0.11 & & & & & & & & & \\
\hline & NQ_S3 & 416 & 84 & 16123 & 30 & 457404 & 9392 & -0.09 & 0.05 & 95 & 0.23 & 0.08 & & & & & & \\
\hline & Roots & 396 & 146 & 378 & 155 & 123 & 45 & 0.23 & 0.05 & & & & 23.8 & 50.6 & 13.3 & 1.1 & 2.9 & 13.9 \\
\hline Man2** & Stems & 2327 & 4716 & 1828 & 141 & 3 & 119 & 0.01 & 0.1 & & & & & & & & & \\
\hline & Leaves & 9421 & 7386 & 5029 & 168 & 356 & 625 & 0.41 & 0.06 & & & & & & & & & \\
\hline & Flowers & 7406 & 12072 & 3469 & 116 & 18 & 51 & 0.00 & 0.09 & & & & & & & & & \\
\hline & NQ_S9 & 719 & 87 & 24309 & 43 & 513204 & 16873 & 0.15 & 0.05 & 292 & 0.34 & 0.05 & & & & & & \\
\hline & Stems & 13689 & 2622 & 0 & 154 & 45 & 148 & 0.45 & 0.08 & & & & n.d. & n.d. & n.d. & n.d. & n.d. & n.d. \\
\hline Man3** & Leaves & 8158 & 4023 & 7902 & 129 & 406 & 96 & 0.92 & 0.06 & & & & & & & & & \\
\hline & Flowers & 18136 & 6689 & 8195 & 146 & 23 & 33 & 0.23 & 0.05 & & & & & & & & & \\
\hline & NQ_S1 & 709 & 109 & 22749 & n.d. & 364841 & 9207 & -0.07 & 0.05 & 302 & n.d. & n.d. & & & & & & \\
\hline Man4** & Roots & 2663 & 7465 & 2402 & 386 & 304 & 199 & 0.04 & 0.05 & & & & 2.9 & 1.4 & 2.1 & 0.5 & 3.1 & 2.1 \\
\hline Man4*" & Stems & 6304 & 11954 & 2286 & 457 & 75 & 187 & 0.12 & 0.05 & & & & & & & & & \\
\hline & Leaves & 7748 & 10471 & 5056 & 199 & 933 & 425 & 0.53 & 0.05 & & & & & & & & & \\
\hline
\end{tabular}

Table 2 


\begin{tabular}{|c|c|c|c|c|c|c|c|c|c|}
\hline \multicolumn{2}{|c|}{ Plant } & \multicolumn{2}{|c|}{$\Delta^{60} \mathrm{Ni}_{\text {soils-DTPA }}$} & $\Delta^{60} \mathrm{Ni}_{\text {roots-DTPA }}$ & $\Delta^{60} \mathrm{Ni}_{\text {stems-roots }}$ & $\Delta^{60} \mathrm{Ni}_{\text {leaves-roots }}$ & $\Delta^{60} \mathrm{Ni}_{\text {leaves-stems }}$ & \multicolumn{2}{|c|}{$\Delta^{60} \mathrm{Ni}_{\text {leaves-soil }}$} \\
\hline & & & & & $\Delta^{60} \mathrm{Ni}_{\mathrm{x}-\mathrm{z}}$ in \%o & $\left.{ }^{0} \mathrm{Ni}_{\mathrm{x}}-\delta^{60} \mathrm{Ni}_{\mathrm{z}}\right)$ & & & \\
\hline Jus & & $-0.01 \pm$ & 0.12 & $-0.08 \pm 0.19$ & $-0.02 \pm 0.19$ & $0.22 \pm 0.21$ & $0.24 \pm 0.17$ & $0.15 \pm$ & 0.14 \\
\hline $\mathrm{Hel}$ & Hyp. & $-0.06 \pm$ & 0.09 & $0.13 \pm 0.16$ & $-0.22 \pm 0.19$ & $-0.1 \pm 0.14$ & $0.11 \pm 0.12$ & $0.09 \pm$ & 0.06 \\
\hline Cni & & $-0.15 \pm$ & 0.04 & $0.24 \pm 0.05$ & $-0.17 \pm 0.13$ & $0.68 \pm 0.04$ & $0.85 \pm 0.15$ & $1.06 \pm$ & 0.03 \\
\hline Man & Acc. & $-0.31 \pm$ & 0.10 & $-0.14 \pm 0.09$ & $0.04 \pm 0.14$ & $0.41 \pm 0.17$ & $0.37 \pm 0.22$ & $0.58 \pm$ & 0.18 \\
\hline
\end{tabular}

Table 3 


\section{Figure captions}

Figure 1: Photographies of the sampled species: (a) Justicia Lanstyakii, (b) Heliotropium aff. salicoides, (c) Cnidoscolus aff. urens, d) Manihot sp.) (Raous et al., 2007 for a, b and c, and personal photography for d).

Figure 2: $\delta^{60} \mathrm{Ni}$ values as a function of $\mathrm{Fe} / \mathrm{Ni}$ ratio(a), OC/Ni ratio(b) and $\delta^{60} \mathrm{Ni}$ values of DTPA-Ni fraction. Linear regression of all data (Barro Alto and Niquelândia) is represented in (a) and (b) with correlation factor $\mathrm{R}^{2}$. Black line in (c) represents a linear regression 1:1.

Figure 3: Ni isotope composition for each specimen of Ni-hyperaccumulator and Ni-accumulator species: (a) Justicia Lanstyakii. (4 specimens), (b) Heliotropium aff. salicoide. (6 specimens), (c) Cnidoscolus aff. urens (3 specimens) and (d) Manihot sp. (4 specimens). Error bars are 2 s.d. of NIST SRM $986 \mathrm{Ni}$ for all of the measurements except when the uncertainty from the replicated measurements is higher than $0.05 \%$. Ni contents in the different parts of each specimen are also represented. Mean value of $\mathrm{Ni}$ content in topsoils is annotated for each species and error bars are included in the mark size. *Collected at Barro Alto, **Collected at Niquelândia. 


\section{Highlights}

DTPA extractable Ni in topsoil is isotopically heavier than the total Ni pool

$\mathrm{Ni}$-accumulators exhibit enrichment in $\mathrm{Ni}$ heavy isotopes in aerial parts

Similar $\delta^{60} \mathrm{Ni}$ values for each plant compartment are observed for Ni-hyperaccumulators

Enrichment in heavy Ni isotopes in leaves may lead to a heavy Ni input in the litter 


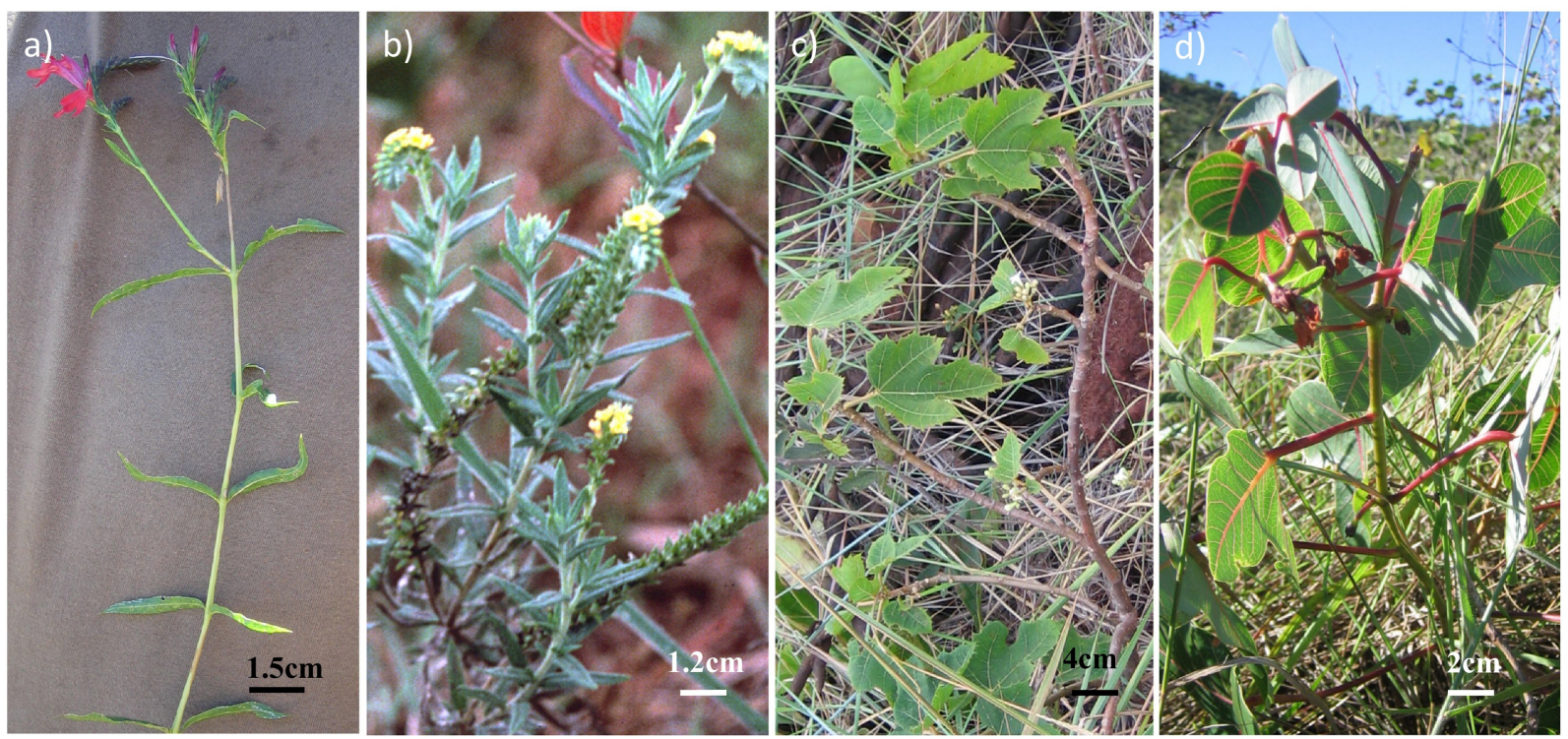

Figure 1 

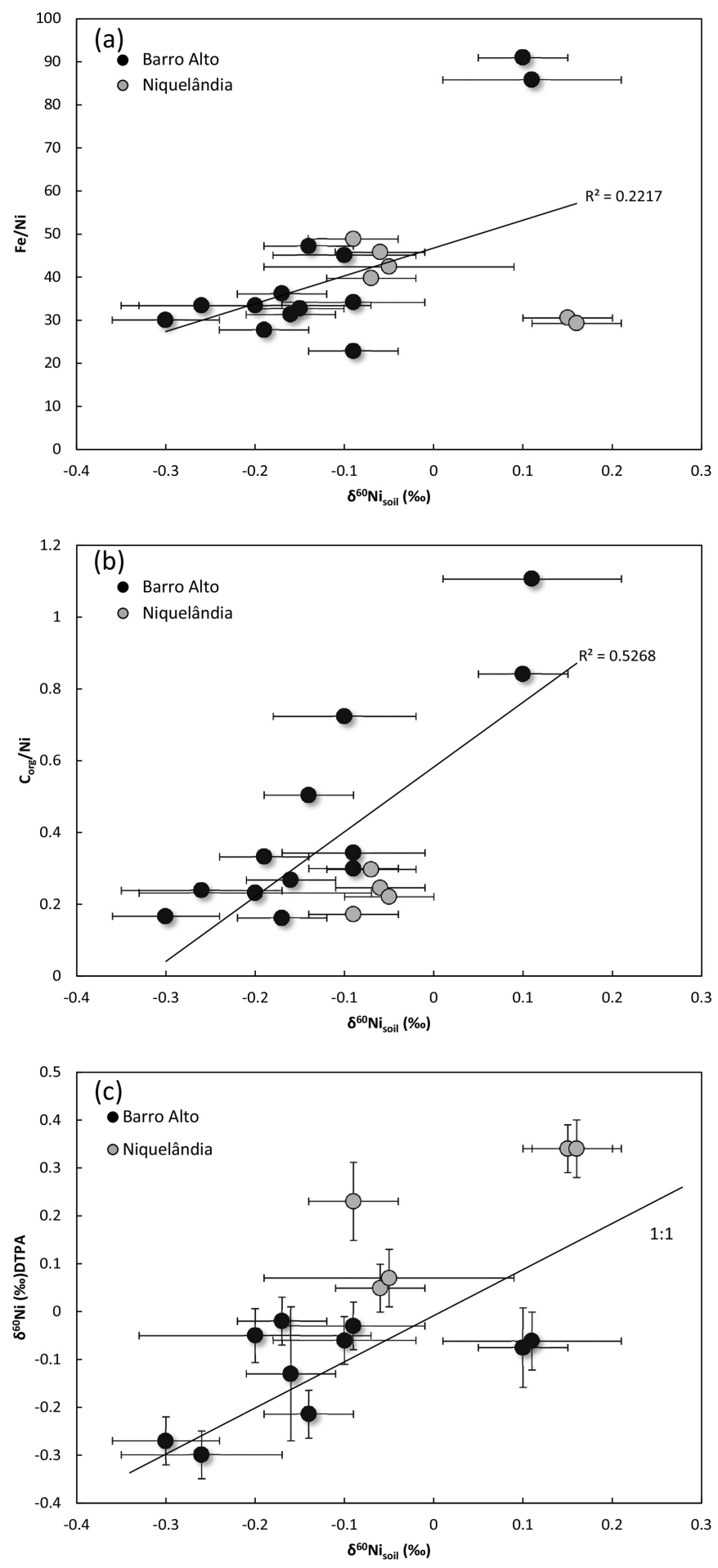

Figure 2 


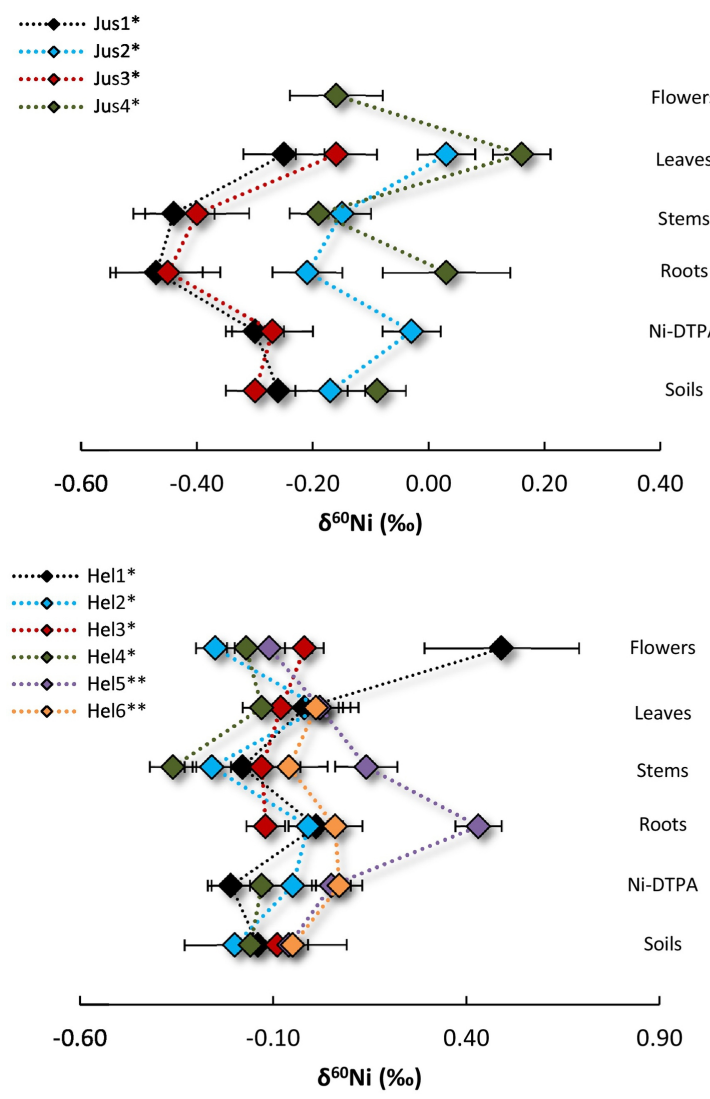

(a)

....४... Jus3*

Flowers

Leaves

Stems
Roots

Ni-DTPA

Soils

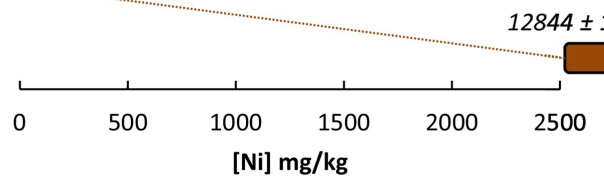

(b)
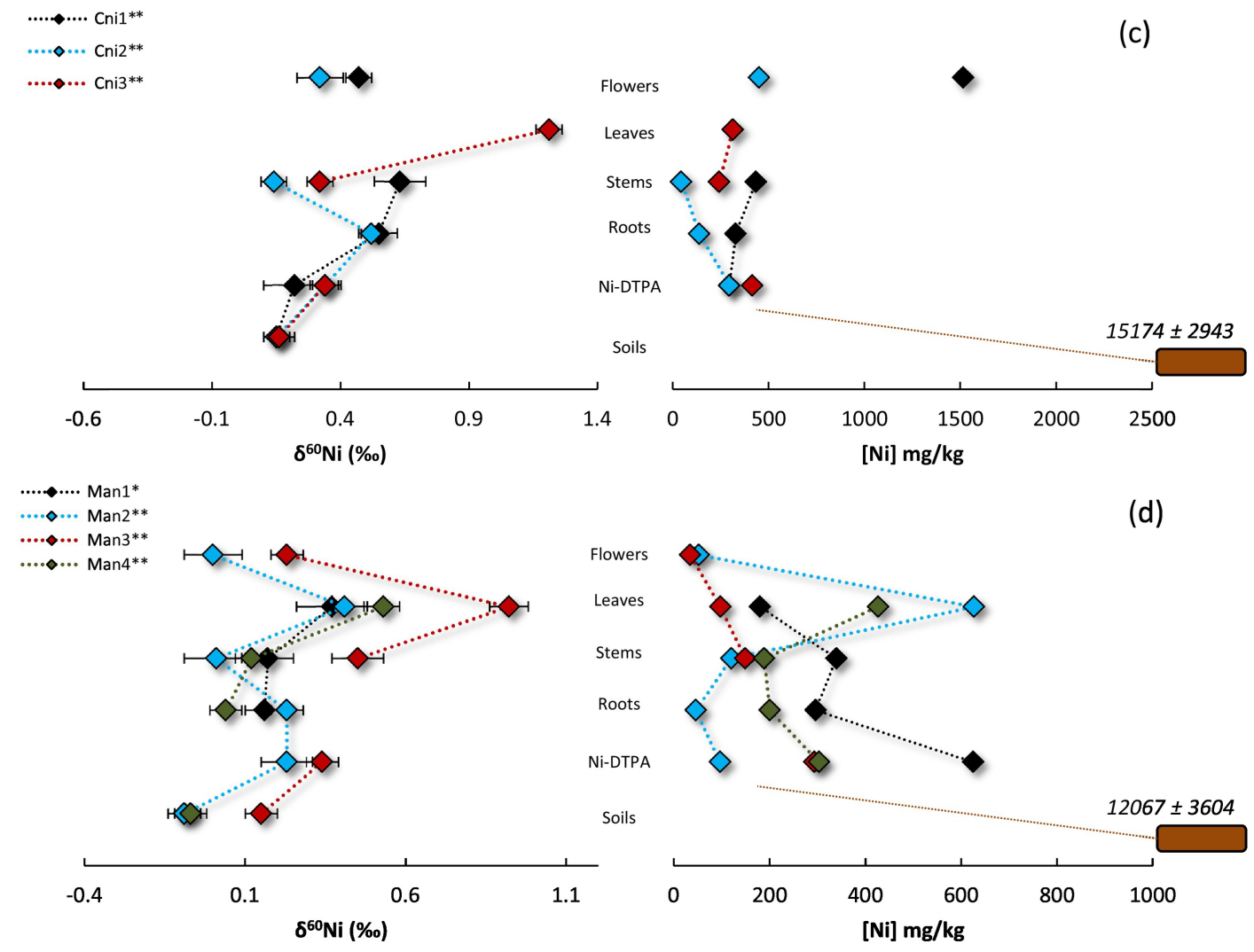

(d)

Figure 3 